\title{
Post-Polemic Space \\ Rethinking the Architectural Identity of an Obsolete Factory Town
}

\author{
by \\ Todd Duckworth \\ M.Arch.Professional, Carleton University, 2010
}

A thesis submitted to the Faculty of Graduate and Postdoctoral Affairs

in partial fulfillment of the requirements for the degree of:

\author{
Master of Architecture \\ M.Arch.Professional \\ Carleton University \\ Ottawa, Canada
}

(C) 2010, Todd Duckworth 
Library and Archives

Canada

Published Heritage

Branch

395 Wellington Street

Ottawa ON K1A 0N4

Canada
Bibliothèque et

Archives Canada

Direction du

Patrimoine de l'édition

395 , rue Wellington

Ottawa ON K1A ON4

Canada
Your file Votre reférence

ISBN: 978-0-494-81629-5

Our file Notre référence

ISBN: $978-0-494-81629-5$
NOTICE:

The author has granted a nonexclusive license allowing Library and Archives Canada to reproduce, publish, archive, preserve, conserve, communicate to the public by telecommunication or on the Internet, loan, distribute and sell theses worldwide, for commercial or noncommercial purposes, in microform, paper, electronic and/or any other formats.

The author retains copyright ownership and moral rights in this thesis. Neither the thesis nor substantial extracts from it may be printed or otherwise reproduced without the author's permission.
AVIS:

L'auteur a accordé une licence non exclusive permettant à la Bibliothèque et Archives Canada de reproduire, publier, archiver, sauvegarder, conserver, transmettre au public par télécommunication ou par l'Internet, prêter, distribuer et vendre des thèses partout dans le monde, à des fins commerciales ou autres, sur support microforme, papier, électronique et/ou autres formats.

L'auteur conserve la propriété du droit d'auteur et des droits moraux qui protège cette thèse. Ni la thèse ni des extraits substantiels de celle-ci ne doivent être imprimés ou autrement reproduits sans son autorisation.
In compliance with the Canadian Privacy Act some supporting forms may have been removed from this thesis.

While these forms may be included in the document page count, their removal does not represent any loss of content from the thesis.
Conformément à la loi canadienne sur la protection de la vie privée, quelques formulaires secondaires ont été enlevés de cette thèse.

Bien que ces formulaires aient inclus dans la pagination, il n'y aura aucun contenu manquant. 


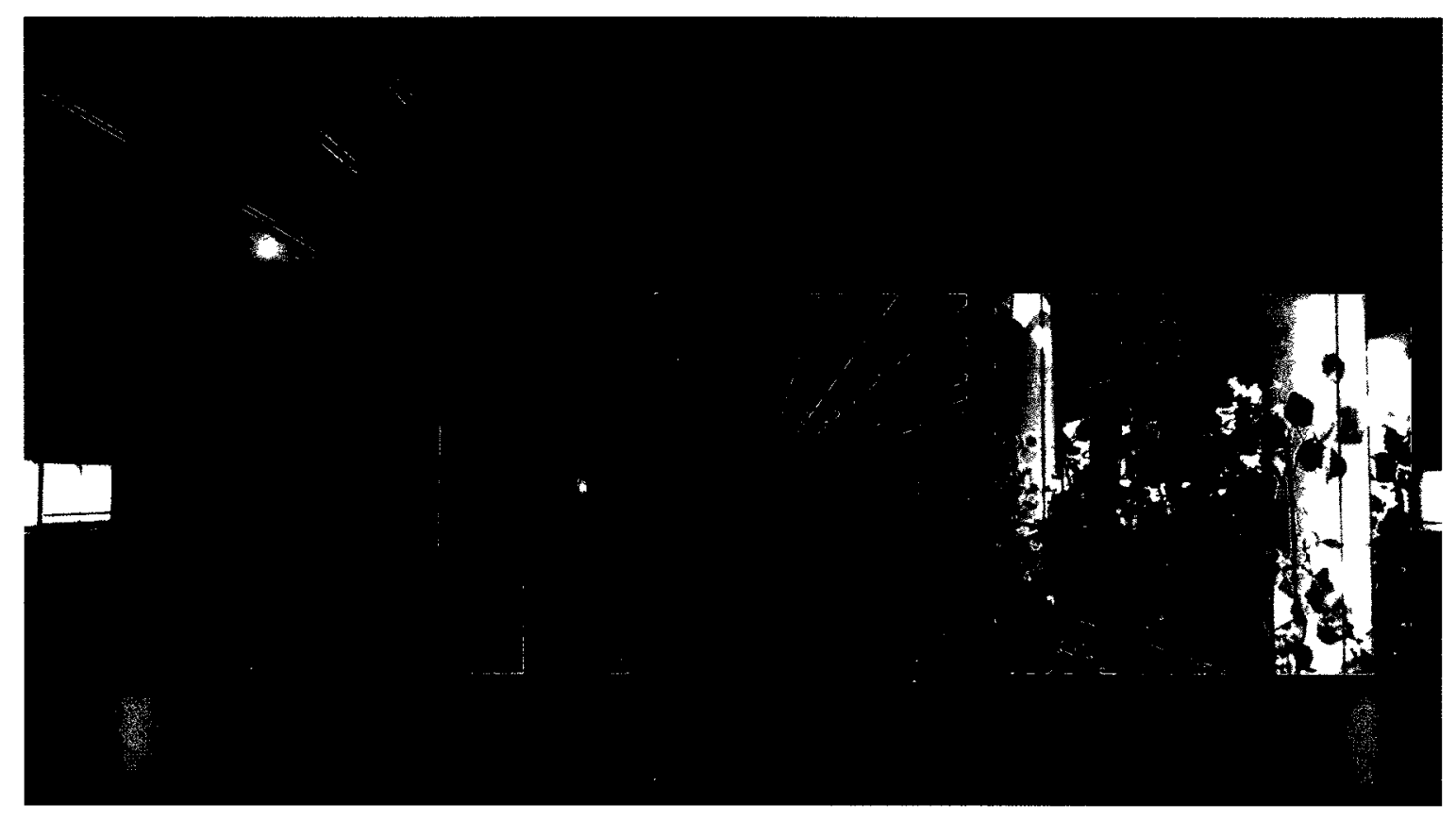


This thesis situates the story of an obsolete Canadian factory town within an historic discourse on the nature of ideal space. Beginning with an investigation of the Platonic idea of Utopia-as a critical theory and then as an optimistic practice-this study arrives at Michel Foucault's rival notion of Heterotopia. Rather than reading these opposing topoi simply as adversaries, however, I argue that Heterotopia is a useful constitution that describes a dialogue between utopian ideals and real contexts.

We conclude with a project of architecture that addresses the town's abandoned factory. Instead of a fixed proposal, this project constructs a heterotopian dialogue that engages the history of the factory through a time-based Building Information Model. This temporal Model is a platform from which to contemplate the future of the factory and the town as part of an ongoing dialogue. 


\section{Acknowledgements}

Thanks to my advisor, Dr. Steve Fai, for his generous dedication and his invaluable

insight. I would also like to thank Jeffery Salmon, Marc Leonard, the Carleton Immersive Media Studio and the Batawa Development Corporation. 
Abstract

Acknowledgements

List of Figures

Introduction 1

\section{Chapter 1: Theories of Utopia}

1.1 The Utopian Genre

1.2 Plato's Republic

1.3 Thomas More's Utopia

1.4 Frederic Jameson: Interpreting Utopia

1.5 The Question of Realization

Chapter 2: Projects of Utopia

2.1 The Practitioner's Imperative

2.2 Garden Cities

2.3 Henry Ford and the Ideal of the Machine

2.4 The Bata Utopia

2.4.1 Socialist Origins

2.4.2 The Advantage of Isolation

2.4.3 The Foreign Influence of Industrial Capitalism 26

2.4.4 Modernist Architecture

Chapter 3: Theories of Heterotopia 33

3.1 Post-Utopia

3.2 Michel Foucault: Extending the Utopian Discourse 34

3.3 A Short History of Space

3.4 Network Space

3.5 The Sovereign Citizen

3.6 From Infinite Semiosis to Context

Chapter 4: Project 46

4.1 Towards a New Heterotopian Architecture

4.3 BIM as a Heterotopian Method

4.4 Project as Dialogue 


\section{List of Figures}

Figure $1 \quad$ Woodcut Map of Utopia. By Abraham Ortelius.

Figure 2 Plan of Palmanova, Italy. http://eyeteeth.blogspot.com/2010/05/google-earth-fortified-city-of.htmI

Figure 3 Diagrams of Ebenezer Howard's Garden City. Fishman.

Figure 4 Housing neighborhood. Fordlandia, Brazil. Grandin.

Figure 5 Residential District. Zlin, Czechoslovakia. Photo from Batawa Development Corporation.

Figure $6 \quad$ Industrial District in Zlin, Czech Republic. Photo from BDC.

Figure $7 \quad$ Typical Bata Factory Plan. Hornakova.

Figure 8 Tomas Bata Memorial. Zlin, Czechoslovakia. Hornakova.

Figure 9 Two Portraits of Earth. "The Blue Marble" capture during the Apolo 17 lunar mission, and a map of the internet by Barrett Lyon.

Figure $10 \quad$ Interior view of Batawa Shoe Factory. Photo by Steve Fai.

Figure 11 Sectional view of BIM with construction drawing overlay, by author. Drawing from $B D C$

Figure 12 Animation sequence 1, by author.

Figure 13 Interior Temporal BIM sequence, by author. Photo from BDC.

Figure 14 Section Details, by author.

Figure 15 Southwest Temporal BIM sequence, by author. Photo from BDC.

Figure 16 Animation sequence 2, by author.

Figure 17 Northwest Temporal BIM sequence, by author.

Figure 18 Animation sequence 3, by author.

Figure 19 Historic View of Batawa. Composite image, by author. Photo from BDC.

Figure 20 Animation sequence 4, by author.

Figure 21 Axonometric views. Temporal BIM Sequence, by author.

Figure 22 Animation sequence 5, by author.

Figure 23 Interior of factory. Composite image, by author. Photo by Steve Fai.

Figure 24 Proposed Condominium project for Batawa Factory, by Zeidler Partnership Architects.

Figure 25 Interior perspective of 2 proposed programs, by author.

Figure 26 Axonometric rendering, by author.

Figure 27 Axonometric detail of proposed modular system, by author.

Figure 28 Axonometric demonstration of proposed modular system alteration, by author.

Figure 29 Axonometric rendering, by author. 
to my parents, and to my wife Jasmine. 
"As a representation, the Modernist utopia may have depicted the annihilation of variety, but as an artifact in context, it was an addition to the reservoir of possibilities." 1

The concept of space in western consciousness is framed by opposing paradigms. The first, the utopian-with representatives ranging from Plato to Thomas More to Le Corbusier-posits a belief that beauty, justice and truth are universally transferable ideals. The second condition-whose representatives include Galileo, Nietzsche, Foucault and Venturi-conversely dismantles any such totalities.

This opposition has permeated much of the architectural discourse of the 20th century. Today it is clear that neither extreme has prevailed over the other, but their conflict has had casualties:

Batawa Ontario was founded as an ideal industrial community of the Bata Shoe Company in 1939. It was built in the Czech company's distinct modernist approach to planning and architecture, which was highly influenced by the Garden City Movement, functionalism and the International Style. This design language was regarded as an embodiment of the Bata Company's corporate values that stressed community solidarity through shared work. In the late 1990s, however, shoe-making in Batawa ceased permanently; its solidarity was dissolved by an increasingly globalized, postindustrial economy and it shared in the fate of so many other factory towns in North Americaobsolescence. The question of Batawa's future is an important one to be considered, as it relates directly to the larger question of what to make of the factory town typology in the twenty-first century.

At its founding, Batawa reflected the utopian belief that an innate link exists between ideology, practice and form. Through its brief history and eventual decline, however, Batawa became another kind of place. Michel Foucault contrasts the idea of Utopia with

1 Sorkin 16 
a rival topos he calls Heterotopia. While he describes Utopia as a comforting fantasy whose universality "permits fables and discourse," in Heterotopia he posits an equally radical subjectivity. Heterotopia is a place with a broken syntax, in which any common understanding or shared meaning is impossible. If Utopia is a picture of society's perfection than this alternative represents society's ruin-a place that no longer functions or makes sense. Batawa's abandoned Shoe Factory has become such a place. The polarity between its original form and its present disrepair is reflected in many manifestations of the utopia/heterotopia opposition: modern versus postmodern, industrial versus postindustrial, clarity versus richness, collective versus self. By reducing a dialogue or story to its unreachable extremes, such oppositions alienate inbetween space and resist the moderating force of context.

This thesis, therefore, will reconsider this perceived polemical standoff and its definitive implications on real space. This is not a reinterpretation of meaning; at question, rather, is the assumption that one extreme necessarily precludes the other in real space. This thesis will investigate the origin and impact of these paradigms, beginning with a study of the utopian tradition, both theory and practice, and then tracing the emergence of the idea of heterotopia as an extension, not a negation, of the same discourse of spatial theory. This discourse will then be situated within the context of Batawa through an architectural project for the Bata Shoe Factory. This project will consist of two main elements. The first will be a digital reconstruction-a Building Information Model (BIM)of the Factory. This Model will reflect a novel adaptation of the BIM tool as it will expand the conventional boundaries of "building information" by incorporating, in a single Model, not only the building's structural and material information, but its cultural and temporal dimension as well. It will be seen that the Factory was, and remains, the product of a dialogue between an architectural idea and a particular context. The second aspect of the project will extend this historic dialogue into Batawa's future through a design proposal for the Factory. Rather than submitting this proposal as a fixed solution, the Factory's modular and adaptable structure will host an ongoing spatial negotiation, between contrasting spaces and programs, that will continue to adapt as the story of the town unfolds. 
This architectural documentation and design project will advance the theory that the rigid outcome of the utopia/heterotopia polarity in Batawa can be revised-that both extents can be made useful and adaptive while retaining their distinctiveness-when seen through the moderating lens of context. 


\section{Chapter 1: Theories of Utopia}

\subsection{The Utopian Genre}

The idea of Utopia originated in literature. Two works from writers separated by nearly two thousand years of western history-The Republic by Plato and Utopia by Sir Thomas More-are jointly credited with co-instigating the Utopian Genre. The template presented in these foundational works has since been appropriated and implemented by many subsequent authors from various social contexts and points in history. The Utopian Genre also overlaps with various other forms of writing, from science fiction and fantasy to political satire and the manifesto. Yet it is a distinct genre set apart by a defining investigation into the relationship between ideology and place. The etymology of More's neologism Utopia pairs the Greek word topos or "place" with a conflation of prefixes: eu meaning "good" and ou meaning "not."1 Utopia is, therefore, simultaneously a good place and an imaginary or non-place.

The objective of the Utopian writer is to present a critical counterproposal to their contemporary circumstance by imagining a perfect context in which a morally ideal society and way of life can be posited. These fictitious realms present often literal inversions and negations of a real social problems. While Utopias are representations of cities or states, the civic composition and practices depicted are projections of the disposition and behavior of the author's own version of a morally ideal person. Plato, for instance, introduces his Republic by first defining the just man before altering his focus and projecting his ideal character onto the collective body of the state. Utopia thus condenses the diversity of identities and values present in our lived topos into a single, collective personality in which all "utopian citizens" participate. This shift in scale, from the disposition of an ideal person to the constitution for the ideal place can be seen as the inaugural utopian gesture.

Despite the noble intentions of the utopian writers, who employed the genre as a valid and effective method of social criticism, it is not difficult to extrapolate totalitarian

1 Hetherington viii 
undertones. This side of Utopia is seen in many of the subsequent iterations where the genre was interpreted as a template for real practice, rather than as an allegorical commentary. While these Utopian Projects will be the topic of my second chapter, for the moment I will touch on another derivative of the Utopian Genre: Dystopia. Like Utopia's shadow, Dystopia represents an opposite view, a fear rather than an optimism. Instead of a society that reflects the personality of a benevolent, moral, and just character, dystopias propose the nightmare scenario in which the dominant figure is cruel and malicious. Relative to real places, "utopias argue outcomes by inversion, dystopias by extrapolation." 2 Yet the two literary forms have comparable aims as critical commentaries intended to propel real societies towards reforming injustice.

For the purpose of this thesis, both utopian and dystopian literature is included under the heading of the Utopian Genre. My reason for classifying these forms as a single genre is that, as I will argue, they are only representational opposites in that they express polar opinions about the same generic, totalized topos. This distinction will become important in my third chapter in which I will introduce Michel Foucault's concept of heterotopia as the compositional opposite of both utopia and dystopia. Presently, I will delve into an investigation first of the foundational utopian texts and then of their implications on real space.

\subsection{Plato's Republic}

Beginning with Plato's The Republic, the Utopian Genre reflects the authors' own conviction on the perceived higher calling of a moral imperative. For Plato, this conviction is simply expressed as the pursuit of justice, which he defines as the "harmony among all parts of a whole entity, each occupying its proper place and fulfilling its intended purpose."* This definition is both formal and spatial and it propels his discourse towards a unique utopian convergence of ideology and place.

The Republic begins with a defense of justice over injustice by first looking to the scale of the individual and seeking to define the ideal person. Plato suggests that everyone's character is composed of a hierarchy of three parts, or grades of inner metal: Gold is reason, Silver is spirit and Iron is appetite. While an unjust person will be

\section{Sorkin 8}


disproportionately driven by appetite over reason, the just person will observe the hierarchy in which each lesser metal submits to the one greater than itself. This inner hierarchy, which governs the just person's disposition, extends outward to inform the wholeness of the ideal state, in which each of the three metals denotes a distinct class of citizen: Gold is the ruling class, Silver is the law enforcement, and Iron is the labour class. Plato's reconfiguration of the state is therefore based on his postulation of a system of criteria through which people find their proper, or just, place in society. The Republic is also organized to dissolve any competing notions of wholeness or belonging, which one might derive from family, from possession, or from social class, and it reorients all citizens to the single wholeness of the state. Everything and everyone is the shared property of the collective. Happiness and suffering, successes and failures are to be measured corporately; if one part of the (collective) body feels pleasure or pain, the whole body feels it. To Plato, there is nothing worse than a fragmented State disproportionate and inequitable. ${ }^{3}$ Social class, he argues, should not be hereditary. Instead, all citizens should acknowledge the quality of their own inner metal and accordingly accept either a higher or lower position in society. For the sake of a prosperous collective, the efficient and just distribution of all citizens is prioritized over any relational attachments or personal aspirations.

Throughout his discourse, Plato draws frequent parallels between the micro and the macro (from the individual to the state) and between the immaterial and the material (from justice and beauty to policy, practice and form). These transcriptions establish the problematic and persistent myth that theory, representation, and practice are innately linked by objective truths and can be translated "as undisturbed as light passes through glass." 4

\subsection{Thomas More's Utopia}

While Plato can be credited with the advent of the utopian constitution, it was not until the sixteenth century, when Thomas More revisited the idea of an ideal society in his fictitious travel narrative that 'utopianism' could be formalized. While Plato's discourse

\footnotetext{
${ }^{3}$ Plato Book 6

4 Forty 31
} 
speculates about the convergence of the ideal character and the ideal place, More's text presumes that this convergence has already taken place.

More appropriates the ideological framework of The Republic for his own agenda. Like Plato, More's starting point is a moral conviction against the injustices that stems from greed, materialism, ambition and the exploitation of power and privilege. Plato's modelstate becomes More's critical frame for evaluating the social challenges and for speculating on possible remedies.

In Utopia, both money and property ownership are abolished, (gold is only used to make chamber pots and the chains of slaves) and citizens consider themselves tenants rather than owners of the land they inhabit. The only trades practiced are the ones deemed essential for the well-being of the collective, including agriculture, wool-working, linen making, masonry, metal working, and carpentry. No trade is more highly regarded than any other. Since many of the social problems being criticized are attributed to pursuits of personal luxury or superfluity, in Utopia they are avoided altogether. The purpose of each citizen is oriented towards the collective well-being of the state, while competing allegiances one might have, such as familial or civic bonds, are scattered through legislations of numeric equalization. If any of the utopian cities (there are fifty-four) surpass the prescribed population limit, they are to relinquish their excess numbers to those cities which are under-populated; households are to observe the same practice, keeping within a range of ten to sixteen adults. When this limit is surpassed they must also release from their own numbers to augment smaller households. Individuality in Utopia is suppressed; from clothing to houses to cities, each example is nearly identical to the next, removing any possibility for one to be visibly distinguished or honored. In the areas of utopian society where it is necessary for some to possess greater authority and stature than average, such as governance or the practical need to assign one city the title of Capital, every effort is made to dismantle the typical association between special power and special privilege. Employment in politics is, therefore, not to be regarded any more highly than in any other trade.

While the constitution of Utopia essentially recapitulates that of The Republic, More's text makes important and original contributions that add to Plato's discourse. Beyond 
introducing the neologism "utopia" itself, More also introduces the ideal person as one of his characters, and the ideal place as the setting for the narrative. While Plato had outlined what both of these might look like, he left them hypothetical and anonymous. Through the account of More's protagonist, Hythloday, a traveller who has returned from Utopia, we learn of the country's history, of its founding and of its founder King Utopus. Utopus, upon conquering the territory that would become Utopia, "brought the rude and uncivilized inhabitants into such a good government, and to that measure of politeness, that they now far excel all the rest of mankind." In the character of Utopus can be seen an impression of the philosopher king which Plato deems the ideal individual to lead the ideal state. While More only describes Utopus briefly, the character's disposition can be extracted from the description of the utopian state he founded. This implies a rational and benevolent character concerned with Plato's ideal justice and beauty in all manifestations which effect the state: political, practical, spatial, social and aesthetic. On one hand he is moderate, allowing citizens their choice of trade and academic pursuits and granting a radical level of religious freedom. At the same time Utopus is stern and authoritarian, as seen in the many restrictions he imposes on utopian society for its own good. Idleness is not tolerated, nor is personal privacy. And religious tolerance is limited by the strict law that all citizens must acknowledge a principal ruling god, (the root cause of justice and truth) and the immortality of the soul: "for [utopians] all [...] believed that there was a state of rewards and punishments to the good and bad after this life; and they now look on those that think otherwise as scarce fit to be counted men." 6

Utopus shares the Platonic belief in the transferability of meaning; that space and form can embody the same universal justice. At the beginning of the history of the ideal state, Utopus lays out a model city that is implemented across the country. "He that knows one [...] knows them all;"; spatial and formal equality seem to have been the guiding design principal. His plan also attributes the greatest importance to the gardens, since gardening was to be the highest order of leisure for the citizens of Utopia. Finally Utopus recognizes that the ideal state must be self contained and isolated from all other

\footnotetext{
5 More (Book 2) 28

6 More (Book 2) 67

7 More (Book 2) 30
} 
countries to establish Utopia as a complete counterproposal to the rest of society and to prevent external influence from diverting its ideal justice. Utopus therefore ordered for a "great trench" to be dug, to make Utopia an island and sever its territory from all others. This act of physical disassociation demonstrates what would subsequently become the standard precondition of the Utopian Genre: a clean break from contemporary circumstance-a do-over.

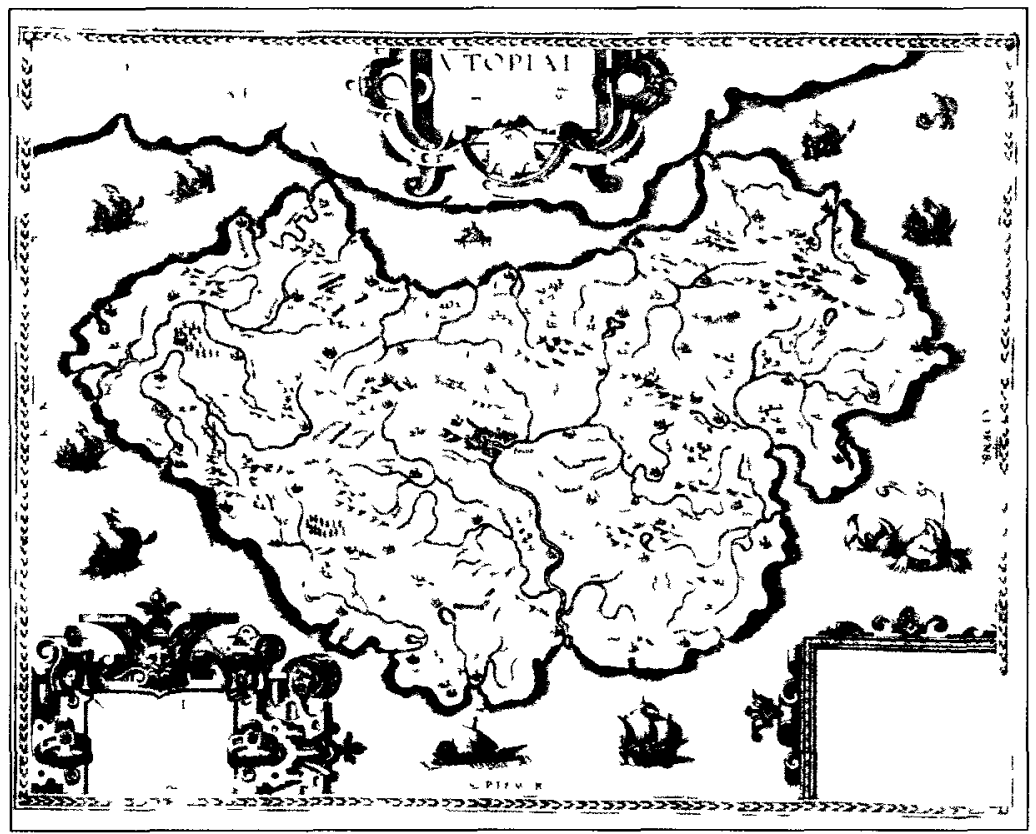

Figure 1- Map of Utopla

\subsection{Frederic Jameson: Interpreting Utopia}

In his book Archaeologies of the Future, Frederic Jameson investigates a broad range of utopıan thought and expression, pursuing the generic nature of the "desire called Utopia" from various manifestations across history. Two of Jameson's significant contributions to utopian discourse are his identification and characterization of the operation of Utopian Production and of Utopian Composition.

The process of generating a version of the Ideal state, Utopian Production, is propelled by a specific kind of motive that gives way to a corresponding methodology. Jameson characterizes Utopian Production as a two-step operation beginning with a manifesto or "ideology" and following through with practical action or "science." As previously stated, the genesis of each Utopia is found in its author's moral conviction. This critical motive is then sharpened into the identification of a single fault within contemporary society that 
is cited as the root cause of all of its other flaws: materialism for Thomas More, social inequality for Edward Bellamy, totalitarianism for dystopian writers such as George Orwell and Aldous Huxley; all are variations on a theme of Plato's generic "injustice."

Utopia reveals in the human personality a recurring desire for the fresh start; to apply the lessons learned from past failures to a new, blank canvas in which the usual societal flaws will be preempted through careful scripting. Following the initial moral criticism, therefore, is an equally focused proposal for its remedy. Upon identifying the core flaw, the Utopian must offer to "solve the fundamental social problems to which [he] believes himself to hold the key." The imaginary, reconfigured state is constructed around a practical "single-shot" 8 response that demonstrates a solution to (in Utopia), or a cautionary exaggeration of (in Dystopia) this main fault. While the resulting fictional societies are often highly resolved, taking into account the most minute of details, and thus are strangely believable as potential realities, they are ultimately unrealizable since they are the radical diffusion of only a singular set of solutions to a singular set of problems.

Jameson notes a natural affinity between the Utopian Genre and Science Fiction, by recognizing in Utopian Production an underlying impulse towards otherness. Through the utopian practice of "radical secession," the utopian state will necessarily commit to closure, cease to participate in a broader context, and withdraw entirely from the society on which it is a reflection and critique. To preserve its self-contained ideal, any Utopia must exist outside the regular flow of time. Thomas More's symbolic withdrawal, achieved by the digging of a great moat, is reflected in all subsequent utopias. In Bellamy's Looking Backward, for instance, the one hundred and thirteen year stasis, from which protagonist Julian West awakes to a utopian transformation of Boston, is a temporal equivalent to More's geographic divide. Still, the greatest withdrawal proposed in the Utopian Genre, as in Science Fiction, is that of the reader: from the familiar into the thoroughly foreign, alternate realm imagined by the author. There is however, as Jameson notes, an inherent contradiction that emerges in the utopian quest for otherness and secession, or at least limitations that become apparent, since each

\footnotetext{
8 Jameson 11

9 Jameson 15, 5
} 
representation of the ideal state, however novel, cannot escape being a product of a particular time, place and circumstance.

"Nothing in the mind that was not first in the senses [...] even our wildest imaginings are all collages of experience, constructs made up of bits and pieces of the here and now. [...] For the more surely a given Utopia asserts its radical difference from what currently is, to that very degree it becomes, not merely unrealizable but, what is worse, unimaginable."10

In light of the incompatibility between utopian otherness and the specific, familiar cultural content of which the utopian state is composed, Jameson instead suggests that utopian otherness is not necessarily found in a place, but rather in a method of representation:

"Can we invent a way of reading More's Utopia (1516) so as to recover something of the shock and freshness of its elegant new Latin for the first European readers? Not the components, however, nor even their individual modes, but rather the unaccustomed combination of hitherto unrelated connotations, make up this generic hapax legomenon; and a type of syntax which might ordinarily say "humanism" finds itself oddly transformed as part of a complex message which is itself a kind of semantic 'one of a kind'."11

Utopia, thus expressed, is an assembly of parts. Clearly the various cultural forces which More stitches together to generate his ideal country are products of his own unique moment in history. Jameson identifies four such elements: the intellectual revival of Classicism and the Greek language; the enclave of the medieval monastery; the exoticism (otherness) of the New World, particularly the social and economic communism of the Inca empire; and (ironically, given More's well-known abhorrence of it) the emergence of Protestantism, perceived as a revival of early Christian communalism. ${ }^{12}$

\footnotetext{
10 Jameson xiii, $x v$

11 Jameson 22

12 Jameson 24 - 27
} 
Not only did these specific cultural forces each manage to embody utopian adjectives which have proven generic enough to broadly retain their relevance in subsequent epochs, they also fit together with a special resonance, converging into a new form of expression which magnetically draws in a disparity of human aspirations and provides a common template for the timeless desire for a transfigured identity. The characteristic otherness that eludes the utopian state itself is faithfully embodied in the methodology through which it is represented. Consequently, More's one-of-a-kind text was extended into a one-of-a-kind genre.

\subsection{The Question of Realization}

It is clear that Utopia was not considered by its early proponents to be an ultimately attainable goal. In the case of Utopia, etymology alone is telling of More's opinion relating to the question of realization; while the title, in part, means "no place," the protagonist's name "Hythloday" means "Nonsense."13 Yet even as a satire, More's purpose for writing, and the injustice he calls attention to, is serious and legitimate. It can be deduced that More hoped to affect incremental reform to societal attitudes and practices through this pointed thought experiment.

More's intent would be in-keeping with that of Plato. In Book X, Plato distinguishes between the ideal and the practicable by outlining the relationship between idea and realization. The idea of a thing is its "truest" form, of which there can be only one and whose author must be God. Any physical realization is inherently subordinate to the divinity of the idea from which it emerged: like a carpenter's chair, which is an "approximation" of the universal idea of "chair."14 Paradoxically, it could be observed that both Plato and More themselves are in fact only "craftsmen," formulating word pictures of the ideal state. Under Plato's criteria, no single project can truly be claimed to be the perfection of the topos, but only one of a potentially infinite number of suggested programs for improvement. Yet for one to posit a Utopia, either literary or realized, is to assume upon one's self a kind of divinity, even if it is only in an imaginary realm; it is to

\footnotetext{
13 Jameson 22

14 Plato, Republic Book X
} 
imply that all other utopian variants are impostors to the extent that they differ from one's own vision.

When confined to a literary Genre, the fundamental incompatibility between utopian totalities is safely theoretical. Since utopian writers are in the business of imagining places, they can each freely imagine a world beyond their Utopia's boarders where no other iteration but their own exists, just as freely as they can imagine the Utopian state itself. When such absolutes are translated to a literal pursuit however, this preclusion takes on an entirely new dimension that necessarily ends in failure, and occasionally, in disaster. Yet as Plato asserts, the practical goal of closely approximating the ideal state is difficult but not impossible. Rather, it is contingent upon the rare instance when the right character, as founder and leader, is situated in a time and place that is receptive to the utopian program. 


\section{Chapter 2: Projects of Utopia}

\subsection{The Practitioner's Imperative}

As outlined in the previous chapter, two literary works mark the foundation of utopian thought. These works voice what seems to be a latent societal desire, or perhaps even a discrete inclination within human nature itself, for ideal and totalized solutions to social problems. While Plato first introduced the Utopian constitution, Thomas More deepened its presence in the western cultural consciousness by setting this constitution to a narrative; Utopia thus became a place that the imagination could inhabit. While it is clear that More regarded his Utopia as a work of fiction rather than a literal template for practice, his text represents a key step along what seems to be the inevitable trajectory from Plato the realized Utopian Project.

In fact, later in More's own century, architectural experimentation with ideal cities were already taking place at sites such as Sabbioneta and Palmanova in northern Italy. Each of these cities, both featuring work by the prominent Renaissance architect Vincenzo Scamozzi, were commissioned and built all-at-once as military fortresses, since "the best practical excuse for

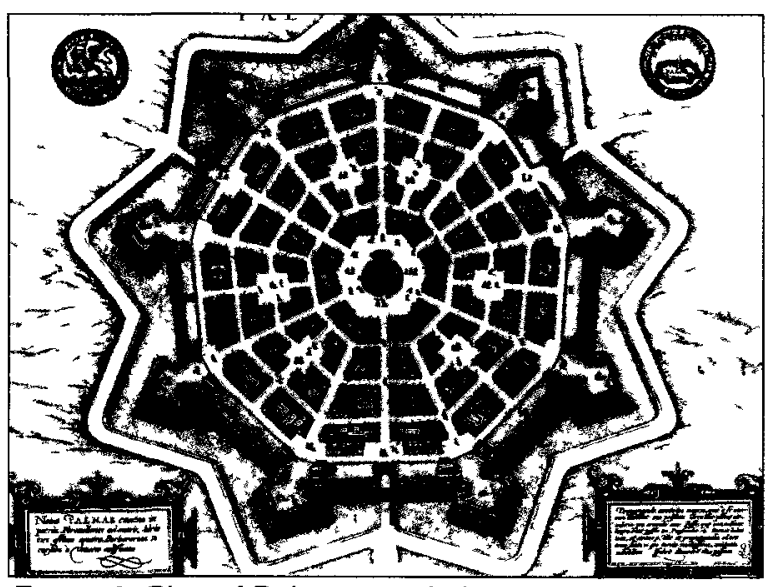

Figure 2: Plan of Palmanova, Italy such perfection was defense or fortification."1

The fact that these planned settlements were never fully populated could be seen as an early lesson in the efficacy of utopian practice. Still, it could also be argued that these experimental cities failed because they were predominantly formal and technological

\footnotetext{
1 Harbison 84
} 
exercises, a kind of Utopian Science that was never associated with a clear Utopian Ideology to justify such "geometrizations of life."2

Like their literary counterparts, Utopian Projects are dependent on the same criteria for their genesis and production, beginning with a convincing moral imperative that is then translated into a critical practice aimed at ameliorating a root flaw. Jameson has pointed out that utopian discourse has not been constant in western history, but has only appeared sporadically, when the cultural and political climate was receptive to its totalizing program. ${ }^{3}$ Though More's Utopia is a product of early western modernity, coinciding with many of its defining innovations and developments ("the conquest of the New World, Machiavelli and modern politics, [...] Luther and modern consciousness, printing and the modern public sphere"4) it was not until a later advent of modernity, the industrial revolution, that a circumstance conducive to real utopian practice would arise.

With the rise of factory production in the nineteenth century, industrial space began to supplant living space in cities, and the influx of factory workers led to an unprecedented level of urban squalor. Over the course of the century, many of the world's largest cities experienced population increases of more than five hundred percent. ${ }^{5}$ The metropolis was often likened to a terminally diseased body, "its circulation clogged, its tissues dying of their own noxious waste;" 6 it was regarded as an inhumane, inefficient and unjust environment which consumed and squandered human vitality. Within the "evils of industry" was found a new moral imperative so pressing that it stirred practitioners, including architects, planners and industrialists, to utopian action while simultaneously convincing populations of the need for the sweeping proposals these practitioners would generate. The condition of the "old city" became the back-story for a period at the turn of the twentieth century in which utopian practice flourished in many disciplines. While the scope and effectiveness of many of these projects were limited to their discipline of

\footnotetext{
2 Harbison 84

3 Jameson 10, 11, 37

4 Jameson 1

${ }^{5}$ Fishman 11

${ }^{6}$ Fishman 12
} 
origin-utopian fragments, rather than Utopias proper-the flurry of focused utopian activity created an environment that eventually affected a more totalized realization. In this chapter I will investigate pertinent "utopian fragments" from the disciplines of urban planning and architecture and from industrialized production as a preface to my investigation of a particular Utopian Project-the Bata Utopia-in which the influence of such fragments is assembled and synthesized into a realized, comprehensive whole.

\subsection{Garden Cities}

At the turn of the twentieth century, planners and architects became actively engaged in ideal counterproposals to the contemporary industrial metropolis. They believed that design could be an active force in realizing the fervent hope promised by industrialization and for Plato's justice to be manifested in the city. Many of the utopian practitioners of this era looked to industry not as an enemy to be overcome, but instead as a means through which a "higher level of civilization"7 could be achieved. They saw within industrial systems an inherent order and efficiency, as well as many new technological opportunities that if harnessed, could bring people, nature, and industry into equilibrium.

The idea of the Garden City was "invented" by self-taught planner and urban theorist, Ebenezer Howard. Howard presented a comprehensive program for an entirely new arrangement of urban space in his publication Garden Cities of Tomorrow, first released in $1898 .^{8}$ There is a natural affinity between utopian thinkers, and inventors since they are mutually concerned with devising seemingly practical solutions to real problems; 9 "Howard had inherited that tradition in English utopian thought in which it was assumed that society could be improved just as a machine could-through the appropriate adjustments."10

Howard confronted inequities of the industrial metropolis with a practical plan for attaining a cooperative socialist environment-a vision he shared with many

\footnotetext{
7 Fishman 4

8 Fishman 23 - Howard's work was originally published in 1898 as To-morrow: a Peaceful Path to Real Reform and subsequently re-released in 1902 under the above title.

9 Jameson 11

10 Fishman 41
} 
contemporary utopians, such as novelist Edward Bellamy. His ultimate goal was to replace the old cities with a new model of decentralized sub-urban centers, or Garden Cities. These new cities are clustered in groups of seven self-contained settlements connected by canals and modern commuter railways. Each geometrically arranged cluster, called a "Social City," contains a Central City with a population limit of 58,000, and six smaller, equally spaced, encircling Garden Cities each with a population of 32,000. Both the Central City and its "offshoots" are laid out in a closed, circular plan, signifying their own completeness. Within each settlement, the various urban programs are distinct, each occupying a dedicated concentric ring around a central park and garden. There is an inner ring of cultural, recreational and commercial space; a ring of quiet residential neighborhoods where each family has their own home and private garden; a "Grand Avenue" in which schools and community halls are prominently located; an outer ring of industrial space; and beyond, a continuous greenbelt of parks and farms to limit future expansion. All of the buildings are "placed to secure maximum utility and convenience." 11 Howard's urban proposal is permeated by his belief (also shared by many of the practitioners who followed) in the innately redemptive quality of nature. The emphasis on the garden, the park, and the farm, first seen in More's Utopia, takes on a renewed significance in the Garden City, where nature is regarded as a force capable of ameliorating the negative impact of industrialization.
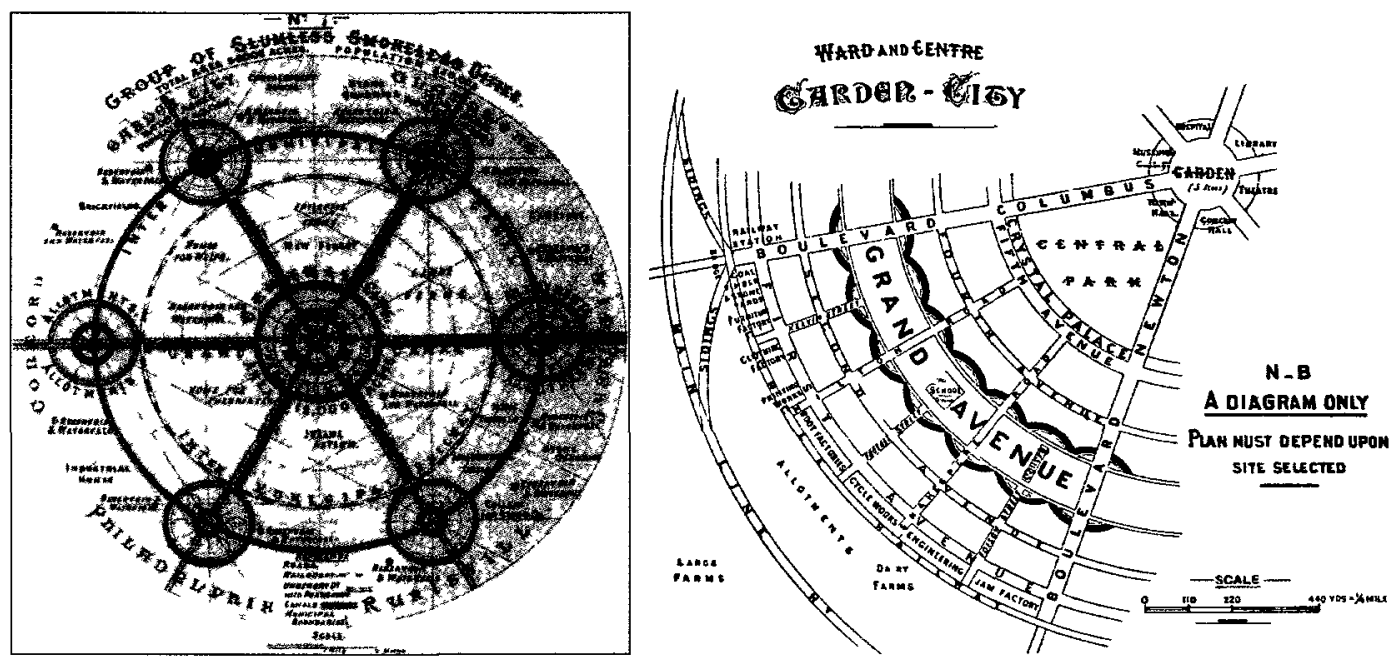

Figure 3: Ebenezer Howard's Garden City Scheme

Howard believed that workers would voluntarily and gladly relocate to his idyllic Garden Cities if given the opportunity. The clear delineation of urban programs in the Garden

\footnotetext{
11 Fishman 41
} 
City is both novel for urban planning at this time and consistent with the utopian project. The scheme was considered to be both economically and socially feasible, ${ }^{12}$ while also embodying the Platonic ideals of justice and beauty: everything in its proper place, fulfilling its intended purpose.

Contemporary to Howard is another influential urban plan, the Cité Industrielle by French architect Tony Garnier. In 1898, Garnier began working on his own Utopian Project that would endow its citizens with all the benefits of modern technology-from abundant, clean electricity generated by the local hydro dam, to modern highways for rapid circulation-within an uplifting garden setting. Garnier further developed the practice, begun by Howard, of differentiating between all the parts of the city according to an "analysis of function and circulation." 13 The plan is based on an elongated rectangular grid (unlike Howard's city, it allowed for expansion) with the core of the city divided into separate zones of residential space and public space. The residential zones are further organized according to housing type, while the public zones are categorically subdivided into administration space, cultural centers, and sports facilities. Encircling the city are various services such as hospitals and alternating industrial and agricultural sites. Like Howard, Garnier demonstrates the characteristically utopian enthusiasm for nature in the urban environment; all of the main areas of the city are separated by greenbelts, while zoning rules restrict the placement and coverage of buildings, resulting in a park-like environment throughout. Among Garnier's most significant innovations was the widespread use of reinforced concrete construction.

This brief period at the turn of the century signifies the moment when "nineteenth century hopes" intersected with "twentieth century technology."14 Each of these hypothetical but practicable proposals demonstrated that the oppression of the city by machines could, in fact, be overcome through a mechanical reordering of the city.

\footnotetext{
12 Fishman 57, Wiebenson 17

13 Wiebenson 22

14 Fishman 15
} 


\subsection{Henry Ford and the Ideal of the Machine}

"The [Utopia] must be a solution so obvious and self-explanatory that every reasonable person will grasp it: Just as the inventor is certain his better mousetrap will compel universal conviction."15

In 1894, Otto Wagner stated that "nothing that is not practical can be beautiful."16 His assertion is indicative of a trajectory towards a functionalist design at the turn of the century. As Nicolaus Pevsner notes, "the plea for functionalism is the first of [modernists'] sources."17 The origins of this shift can be traced back to the structural inventiveness of nineteenth century engineers whose exposed steel structures openly revealed their function, demonstrating a level of formal honesty which was then unknown in "architectural" practice. Projects such as Joseph Paxton's Crystal Palace (1851), W. H. Barlow's St. Pancras Station (1864), the Hall des Machines (1889), and the many iron suspension bridges of this period, were designed by engineers for mainly utilitarian purposes. However, in part inadvertently, they pioneered a "machine aesthetic" that made beautiful the inner working of things.

When expressed as a technical practice, akin to the inventor's tinkering, Utopian Production can be justified as the pursuit of an objective ideal, just as the inventor benefits from being able to objectively measure successes and failures through quantitative observation.

Industrialist Henry Ford, for whom moral 'goodness' was embodied by mechanical efficiency, personifies the utopian inventor. To Ford, neither the car nor its revolutionary transformation of human mobility was an end goal. Rather his technical inventions were a means to realize the greater socioeconomic ambition of a Utopia in which both his factory production and, more importantly, his nostalgia for wholesome, rural American values could be infinitely self-sustaining.

\footnotetext{
15 Jameson 11

16 Pevsner 164

17 Pevsner 9
} 
To Ford, solving technical challenges with practical solutions was always an act with ideological undertones. In 1914, faced with high absenteeism and turnover rates among his factory workers, he introduced the incentive of an unprecedented pay increase to five dollars per day. Yet in order to ensure that the increased wages did not have an inverse effect on productivity by perpetuating vice, the Five Dollar Day was made contingent on living a "wholesome" life-a policy that required Ford to use invasive, persuasive and even outright forceful methods to police. ${ }^{18}$ In Ford's quest for increased efficiency, the human factor proved to be the most difficult variable to control. The Five Dollar Day, not only purchased the workers' labour, but also a stake in their personal lives.

"The impression has somehow got around that Henry Ford is in the automobile business. It isn't true. Mr. Ford shoots about fifteen hundred cars out of the back door of his factory every day just to get rid of them. They are the by-products of his real business, which is the making of men." 19

One of the greatest challenges that Ford faced as a utopian practitioner was of his own making. While Detroit was a thriving industrial centre, it became apparent to him, as Greg Grandin points out, that "the force of industrial capitalism he helped to unleash was undermining the world he hoped to restore." The underlying sense that "something had gone wrong"20 prompted Ford to a radical secession. Rather than purge Detroit, he looked elsewhere to establish his utopia.

The intersecting desires for wholesome living and efficiency, (ideology and science) and also, perhaps, the influence of the utopian tradition itself, pointed Ford towards the pastoral. Like Howard and Garnier, Ford believed that the farm and the garden could redeem industrialization and the worker while yielding new material and labour efficiencies. With the hypothesis that farm work and factory work could be seasonal occupations employing the same workers, he began buying large tracts of remote and sparsely populated farmland and woodland in Michigan that he imagined to be "blank

\footnotetext{
18 Grandin 70

19 Grandin 34

${ }^{20}$ Grandin 16
} 
canvases on which to paint his vision of industrial-rural wholeness." ${ }^{21}$ This decentralization of industrial production was the means through which Ford could test his 'field and factory' theory. The 'communities' he built were small, sometimes with as few as twelve workers, and were sustained primarily through company subsidization. Ford stated that the program was not a utopian gesture but rather a means of quietly augmenting local village economies. ${ }^{22}$

A more overtly Utopian Project came in Ford's proposal for a new city at Muscle Shoals in a remote area of Alabama. This was a planned linear city along the Tennessee River, "as thin as Manhattan but five and a half times its length," ${ }^{23}$ placing all residents within close proximity to the natural landscape. Though never realized, Muscle Shoals resonated with contemporary experiments in urban planning, most notably with Frank Lloyd Wright, who enthusiastically endorsed the proposal. In Muscle Shoals, the Ford Motor Company proposed low interest mortgages for affordable home ownership, low cost hydro and fertilizer for personal farming and gardening, high wage jobs, schools, and equipment co-operatives. The proposal was a transposition of the efficiency of Ford's factories to the scale of the city. Believing he could engineer a new society, Ford boasted, "We could make a new Eden of the Mississippi Valley, turning it into the great garden and powerhouse of the country." 24 When the proposal was rejected by the United States Senate, Ford's growing utopianism drove him to the depths of the Brazilian jungle where he would build Fordlandia.

Established as a rubber plantation on the Tapajos River in 1928, Fordlandia at first appeared to be a legitimate business venture. However, the practical motive to secure a stable supply of rubber for the company was complicated by Ford's frustrated utopianism. "For Ford, the Amazon offered a fresh start in a place he imagined to be uncorrupted."25 Fordlandia was designed as a model city, in an American midwest

\footnotetext{
${ }^{21}$ Grandin 62

22 Mullin 5

${ }^{23}$ Grandin 65

${ }^{24}$ Grandin 68

${ }^{25}$ Grandin 82
} 
aesthetic. After a troublesome start to the campaign-plagued by mismanagement of resources, difficulty adapting to the climate, failed rubber tree crops, poor living conditions, disease, and worker unrest that culminated in a long and destructive riot in December of 1930 -Fordlandia slowly began to physically resemble Ford's nostalgic ideal. It had paved streets and sidewalks, streetlamps, fire hydrants, and neighborhoods of "modern" clapboard bungalows with metal roofs, which Ford insisted upon despite protests from his onsite manager that they were ill-suited to the Amazon climate. Though Ford never actually visited Fordlandia, he also imposed his own values through everything from laws, school curricula, and the diet of the workers.

Fordlandia was operated by the Ford Motor Company for seventeen years and in that time it failed to yield a significant quantity of rubber for use in Ford products. The campaign had been undertaken without any personnel who were knowledgeable in Amazonian agriculture. Ford did not consider such expertise necessary, instead believing that living things (in this case rubber trees) were like machines and could be regimented as such. ${ }^{26}$ As time passed and the prospect that Fordlandia would become productive became increasingly doubtful, there was a shift in the Company's rhetoric regarding the project. Despite the failure to become economically viable, it was instead celebrated as a humanitarian "work of civilization."27 Fordlandia became "the terminus for [Ford's] lifetime of venturesome notions about the best way to organize society."28 It reflects his misplaced conviction that the mastery of mechanical processes is a universally transferable ideal that translates equally in all undertakings.

Ford's failed Utopian Projects stand in sharp contrast to the industrial innovations that made him the richest man in the world. In view of his achievements, one can begin to understand his faith in the limitless potential of an efficient machine. However, Lewis Mumford's criticism of Plato for reducing the human character to an "obedient

\footnotetext{
${ }^{26}$ Grandin 298

27 Grandin 267

${ }^{28}$ Grandin 8
} 
automaton," 29 could be leveled against Ford's assembly line as "a form of hell on earth that turned human beings into driven robots:"30

Ford's utopianism echoes the machine-like character of many of his literary precedents, in which the utopian citizen (in Ford's case the factory worker) is the primary mechanism. In Plato, More, and Ford alike, the 'objective goodness' of the efficient, productive and self-perpetuating machine of the state is expressed as a universally transferable truth, reflecting both a practical and a moral ideal. This synergic identity, however, always eluded Henry Ford. The radical success of his utopian pragmatism conversely alienated his own utopian ideology to the point of irrelevance. More's ideal character manifested in Ford as two alternate and irreconcilable personas: Ford the master industrialist and Ford the frustrated utopian.

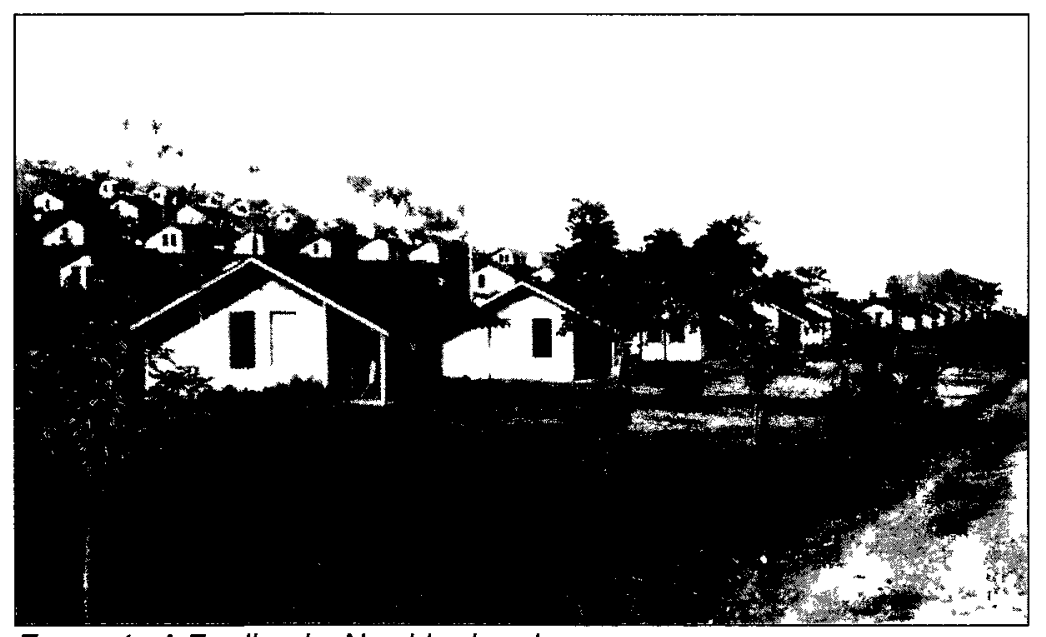

Figure 4: A Fordlandia Neighborhood

\subsection{The Bata Utopia}

Despite a widespread enthusiasm for Utopian Projects in the early twentieth century, More's ideal state remained an elusive goal. While certain practitioners did manage to implement aspects of their grand schemes, it has been aptly noted that "nothing is more discouraging to any idealistic movement than partial success." 31

\footnotetext{
${ }^{29}$ Mumford $174-176$

${ }^{30}$ Grandin 69

31 Fishman 87
} 
Among the Utopian Projects of the early twentieth century, the Bata Shoe Company is a rare exception. The company's founder, Tomas Bata Sr., not only realized a Utopian Project that matched the breadth of More's vision, but Bata's own character resonates with the disposition of More's mythic founder, Utopus. Bata, like Utopus, was a man of both untempered idealism and objective pragmatism, both authoritarian and benevolent.

Bata's Utopia originated in the remote rural town of Zlin, Moravia, now part of the Czech Republic. In 1894 Bata, together with his brother and his sister partnered to establish a small shoe-making business with $\$ 320$ they shared from their mother's estate. By the time of his death in 1932, Bata had grown the company into one of Europe's largest shoe manufacturers, had rebuilt Zlin into a modern industrial garden city, and had founded thirty-two company towns and subsidiaries around the world. ${ }^{32}$ Tomas Bata's Utopian Project followed the simple dictum that "work and service to others" is the "essential source of moral and economic satisfaction." 33 This basic philosophy contains the familiar seed of Utopian Production: pragmatic action routed in an ethical conviction. Bata's objective was no less than to enrich the lives of customers and employees alike while becoming "the shoemaker to the world."

In my study of the Bata Utopia, I will revisit and implement the contextual hermeneutic that Jameson has applied in his reading of More's text. As Jameson identifies the original Utopia as an assembly of four specific cultural moments that correspond to timeless, generic principals, I believe that utopias from any other period can be similarly registered to this original prototype through a contextual investigation. Jameson's four specific examples correlate to four generic categories that account generally for utopian politics, otherness, economy, and form. In the case of the Bata Utopia the specific influential factors are, respectively: socialism, geographic and economic isolation, industrial capitalism, and the modernist movement in architecture and planning. My investigation of the Bata Project will therefore be structured under these four headings.

\footnotetext{
${ }^{32}$ Cekota 9

${ }^{33}$ Bata ix
} 


\subsubsection{Socialist Origins}

"Not one of us is of capitalist origin. Each one of us holds the "ladder of success" for his poor relatives by sharing with them the acquired experiences." 34

In 1919, addressing his employees as "collaborators," Tomas Bata reminisced on the socialist environment from which his capitalist enterprise emerged. In his early years as a cobbler in a rural town, Bata shared the prevailing opinion of his region: that capitalist society was "only good for bad people."35 He was instead inspired by the simple life of Tolstoy, and hoped to retire from his shoemaking business once he had paid off his debts and earned enough money to buy a small farm. To achieve this goal, he actively sought ways to increase the efficiency of his struggling business and soon discovered the revolutionizing potential of the very machines that he associated with the "hated capitalist." At the same time, seeing the workings of socialist politics around him, he had become increasingly skeptical of the cooperative enterprises that contemporary socialists were promoting. "I recall the experience with my brother [and business partner], when each and every work was talked over, but none was done."36 Rejecting the politics of socialism, Bata undertook his own revolution and adopted industrial methods of production for the production of shoes. Embracing the humanitarian aspirations of socialism, he argued for a benevolent capitalism. ${ }^{37}$ These decisions stemmed from a personal conviction which ran deeper than his inherited political leanings: his Utopian Ideology, to "serve the people" through his work.38 Bata made his workers into company shareholders and created "tens of thousands of small capitalists." 39

\footnotetext{
${ }^{34}$ Bata 29

35 Bata 17

${ }^{36}$ Bata 19

37 Bata Phenomenon (Sevecek) 38 - The author observes that the American Style welfare capitalism is combined with typically central European social and managerial values.

38 Bata 19

39 Bata Phenomenon (Platzer) 212
} 


\subsubsection{The Advantage of Isolation}

One of the key traits of the Bata Utopia does not relate to the founding character or his methods, but rather, is simply an outcome of the environment in which the project emerged. The suitable isolation that is ideal for the utopian locale (the pursuit of which sent Ford on his extreme and costly project in the Brazilian jungle) was the natural precondition of Bata's home town of Zlin. While Detroit's population exceeded twohundred-thousand at the time the Ford Motor Company was founded, Zlin's population was less than three thousand when Bata opened his own business. Zlin's economy was based primarily on skilled trades, merchants and farming. It was without electricity and due to the isolated geographic location of the town, it had limited lines of communication to the outside world. "Everyone was equally poor."40 Despite the inherent obstacles involved in developing a competitive, large-scale business within a remote and underdeveloped context, these very shortcomings gave Zlin a natural advantage as a site for a Utopian Project: firstly, because of its small and isolated economy, both land and labour were relatively inexpensive. But perhaps more importantly to the Utopian founder was that the rural town is cut off from the many subversive and revolutionary ideas that emerge in large cities.

Bata was able to reshape Zlin into his own utopian image with relatively little opposition. In 1923, his influential position as the city's most prominent employer was augmented by his being elected mayor-an office he held until his death. This position gave him further autonomy to pursue the dramatic company building campaign (the Bata Construction Division was opened in 1924) ${ }^{41}$ through which he rebuilt most of the city's industrial, commercial, municipal and residential space. ${ }^{42}$

\subsubsection{The Foreign Influence of Industrial Capitalism}

In 1904 Bata travelled to the United States for the opportunity to work in an American factory. He would subsequently regard the level of efficiency and work ethic he witnessed there as the standard against which he measured his own enterprise. "I am

\footnotetext{
40 Bata Phenomenon (Sevecek) 39

41 Bata Phenomenon (Hornakova) 113

42 Bata Phenomenon (Platzer) 212
} 
trying to solve the problem of how to sell shoes for prices as low as in America. We can achieve it only then when a worker in our factory will produce as many pairs of shoes as in American factories." 43

He was particularly inspired by the motivating effect of capitalist competition and its direct correlation to productivity both among corporations and among individual workers. The free competition of American industry seemed to him to offer a solution to the rigid class distinction he had grown up observing in Europe. ${ }^{44}$ He claimed that "to make capitalists from all of our employees is one of the primary objectives of my business." 45 Like the novelty and otherness of the Inca's socioeconomic example in More's day, Bata returned from America empowered by foreign ideas of entrepreneurship which would shape the path of his own practice.

Posterity has been kinder to Bata as a utopian industrialist than to Ford. Consistent among literature documenting the life and career of the industrialist shoemaker is a tone of reverence for his Ford-like successes, while typically only passing reference is made to his Ford-like struggles. Although the accounts are muted, Bata also dealt with worker strikes, criticisms of oppressive paternalism, and with lingering social inequality that stemmed from corporate hierarchy. Nevertheless, there are clear differences that distinguish the two practitioners, both in their objectives and in their methods.

Like Ford, Bata's commitment to perpetual progress was exemplified in his ceaseless pursuit of technical efficiency. Early in his career he discovered the potential of the machine to revolutionize productivity in shoe manufacturing and this initiated his "lifelong desire to get the most out of time and to overcome distance." 46 But unlike Ford, this was more than a utopian obsession. Bata's attitude towards technical progress included innovation by his employees. While Utopia may evoke an image of timelessness, stasis, and arrival, Bata followed More in understanding that progress is a necessary part of the

\footnotetext{
43 Bata 38

44 Bata 11

45 Bata v

${ }^{46}$ Cekota 75
} 
Utopian constitution. Utopus, as the admittedly finite instigator of the infinite state, acknowledges that Utopia should continue to be refined beyond his original guidelines. Jameson has noted that within the Utopia there is adisconnect between the means of realizing the state and its end goal: "Utopus must somehow abolish himself and his monarchy in order to allow Utopia to come into existence." 47 Therefore, while Utopus' founding ideology was to remain constant, "he left to posterity [...] to add the adornment and other improvements for which he saw one lifetime would hardly suffice." 48

While Ford seemed to struggle to write his own centrality out of any of his company's activities, Bata demonstrated his intention that his Utopian Project should outlast the founder: "My work cannot go under and will not. [...] My system will stay in place for the benefit of those who will succeed us." 49 When in 1931, one year before his unexpected death in a plane crash, Bata was asked about his plans for succession in the company, he replied, "I started settling the problem of my succession 36 years ago, at the time I invited the first helper to my stool. Had I organized my work so as to become irreplaceable, I would have never invited helpers."50

Bata recognized the need to dismantle his own centrality and that of his headquarters, Zlin, in order to achieve his resilient and adaptable "system." One of the most defining characteristics of the Bata Company's practice, therefore, became the decentralization of its operations to satellite factory towns around the world. While he had derived the concept from Ford's experimental Village Industry Program, the Bata campaign to decentralize was a practical response to real challenges: the exhaustion of Zlin's supply of skilled laborers, its isolation from major waterways and supply routes, increasingly high taxes, and the need to reach a broader consumer base. ${ }^{51}$ The new Bata towns were to be strategically located, independently managed businesses united by a

\footnotetext{
47 Jameson 37

48 More (Book 2) 29

49 Bata Phenomenon 149

${ }^{50}$ Bata 243

51 Bata Phenomenon (Hornakova) 129
} 
common purpose and methodology rather than by a solitary and indispensable leader. ${ }^{52}$ Decentralization also permeated production methods within the Bata factories. While it was conventional for rows of workers' machines to be connected by a driveshaft to a single power source, Bata resolved to give each station its own source of power. Despite the substantial cost, the impact of this shift was profound, both for productivity (breakdowns were localized to a single machine at a time) and also for the individual user: "a close relationship developed between a man and "his" machine. It grew out of his responsibility for it and his realization of the interdependence between him and the machine" 53

The resilience of the "Bata System" was powerfully vindicated by the upward trajectory of the Bata Shoe Company under the leadership of Bata's colleagues, including his son Thomas Jr., following his death. By the 1990s the company had achieved the status of world's largest shoe manufacturer while still adhering to many of Tomas Sr.'s founding principles.

\title{
2.4.4 Modernist Architecture
}

The Bata Utopia is distinct among its contemporaries in the extent to which its founder's guiding principals (ideological and practical) were successfully manifested in every aspect of life within the company. Nowhere is this reality more apparent than in the distinct, functionalist architectural language that characterized every Bata town.

\begin{abstract}
"Architectural production, like the production of footwear, was subject to precisely defined procedures, based on economy, strict time scheduling and prefabrication." 54
\end{abstract}

\footnotetext{
52 Cekota 9 - It is significant to note that without this decentralization, it is very likely the Bata company would not have survived World War II. In 1939, Czechoslovakia was occupied by Nazi Germany effectively ending Zlin's era as the Bata headquarters. Following the war, "two thirds" of the company were lost to Soviet control, leaving only the Bata towns in Allied territory free to carry on in the Bata tradition.

${ }^{53}$ Cekota 98 - 99

54 Bata Phenomenon (Platzer) 211
} 
Tomas Bata's architectural patronage began when he hired the prominent Czech modernist and student of Otto Wagner, Jan Kotera, to remodel his home in 1911. Over the next decade Kotera formulated a new architectural vision for Zlin through planning strategies that employed both Howard's and Garnier's concept of modern zoning. Corresponding with the company's increasing economic success in the 1920s and 30s the city was rebuilt as a zoned garden city, providing generous amounts of green space, or urban "lungs," throughout. There were dedicated residential districts with private gardens, geometrically arranged in a checkerboard pattern; an outlying industrial district with dozens of factories; and a town center region that comprises both old Zlin as well as new cultural, municipal, and commercial facilities.

One of the most prominent Bata architects of the interwar period was Frantisek Gahura. A student of Kotrera, he was largely responsible for developing the "Zlin Style" architecture. Perhaps most significantly, he contributed to the most distinctive spatial and structural element of Bata architecture a modular reinforced concrete post-andbeam system based on a $6.15 \times 6.15$ meter grid square (corresponding with the $20^{\prime} \times 20^{\prime}$ module adopted from the United States). This became the standard architectural unit of all Bata factories, typically laid out in a $3 \times 13$ bay grid plan and between three and five stories tall. The standard Bata factory facade combined the exposed white concrete frame with infill wall panels of varying ratios of red brick and glazing. Vertical circulation elements such as service elevators and stair cores were also exposed on the buildings' facades, acting as constructivist "frontispieces." 55 The articulation of structure, function and circulation was the primary aesthetic outcome of Zlin Style architecture; an architecture founded on pragmatism, efficiency and spatial equality. During the interwar period, the Bata factory's modular unit was also used for nearly all of the other types of company buildings, both in Zlin and abroad. This included schools, administration buildings, community centers, dormitories, hotels and so on. Even many of the company-built detached homes were related to the proportion of this factory module. "From the outset we attempted to build the town in a way that would grow organically from its industrial architecture [...]"56 The building height and number of bays were modified from the standard system, as needed, to adapt to different building types.

\footnotetext{
55 Ricketts

${ }^{56}$ Bata Phenomenon (Hornakova) 57 - A quote by Frantisek Gahura
} 
Gahura also experimented with various configurations of brick and glass in the system's infill wall panels. The manipulation of the infill panels was an economical means of expressing different building functions in the facade and also a means of adding subtle variety to the stylistic homogeneity of the urban space.

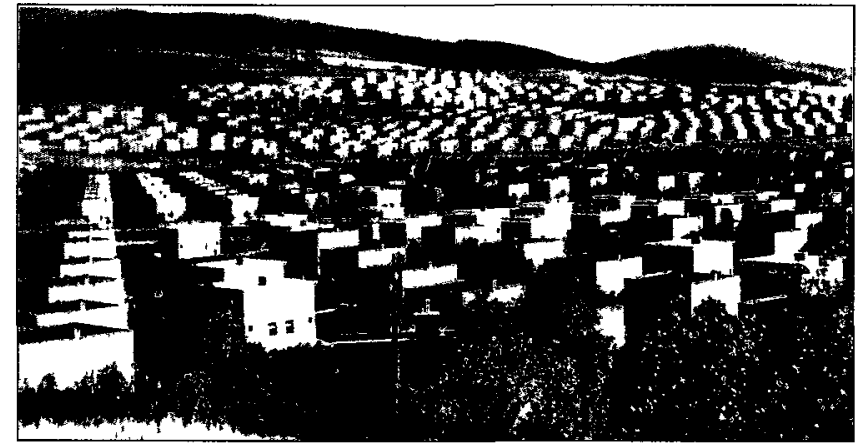

Figure 5: Zlin's residential district

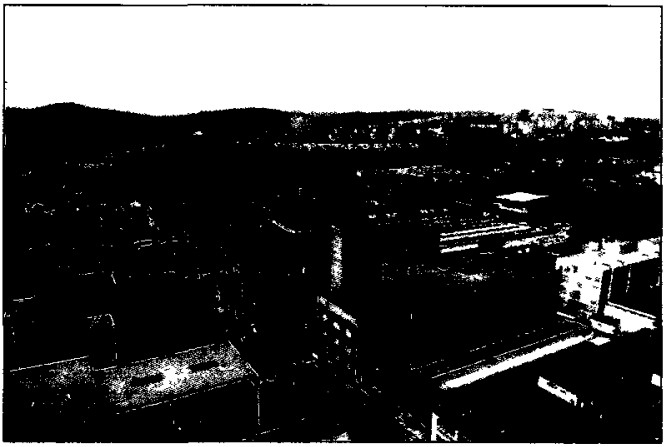

Figure 6: Zlin's industrial district

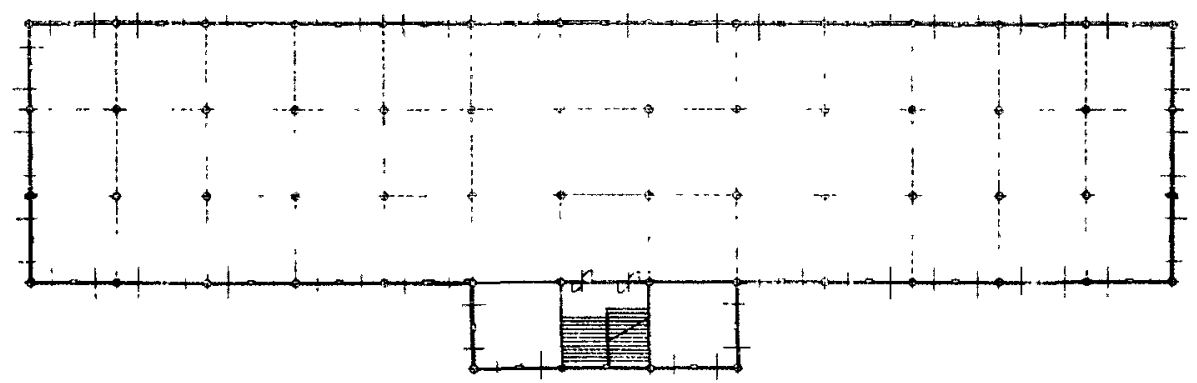

Figure 7: Typical Bata Factory Plan

Gahura's most expressive composition within the Bata architectural language was the Tomas Bata Memorial pavilion, built in Zlin in 1933. The building employs the typical Bata module, arranged in a grid of $3 \times 6$ bays, and it is three stories tall. It is unique among Bata buildings in its strong expression of verticality. The infill walls are continuous vertical glass panels articulated by vertical mullions. Gahura subdues the horizontality of the floor slab edges by receding them from the facade. This "glass crystal," celebrates the founder's utopianism by successfully employing pragmatic factory architecture to convey a sense of the sacred. 
The Bata Company's architecture is a refined synthesis of many of the utopian desires within the modern movement. Zlin effectively became a working, full-scale realization of Garnier's Cité Industrielle, where the machine was tamed by the garden and where citizens enjoyed the benefits of both while living in relative equality. The widespread implementation of a functionalist architecture confirmed both the feasibility and moreover the livability of an entirely modernist city, while the dissemination of the Zlin Style to each of the Bata's satellite company towns enacted and tested the International Style's premise of universality.

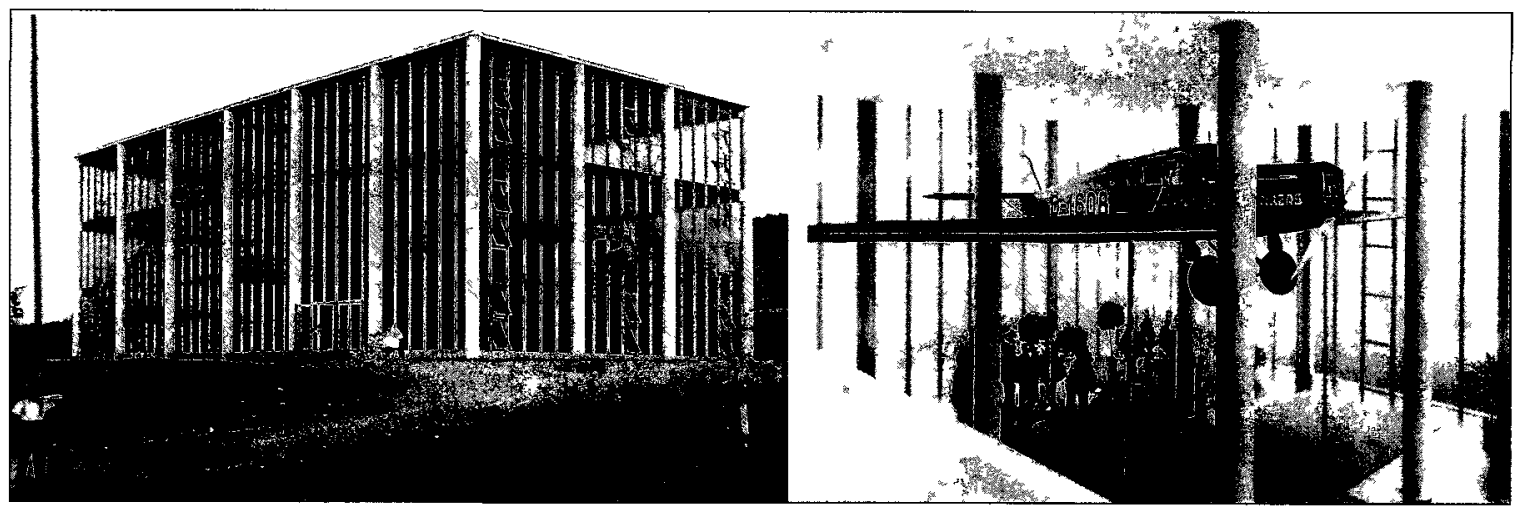

Figure 8. Tomas Bata Memorial, Zlin

The scale of the Bata's architectural achievement reflects the broader success of the Bata Utopia itself, as a comprehensive implementation of the genre in practice. In turn, the success of this utopia-made-practicable reflects the disposition of its own Utopus character. Yet despite the unique success among Utopian Projects, the Bata Utopia is not transcendent; it is not the perfected state. Rather, while it lasted, it was an effective approximation-a "craftsman's copy" - that was achieved by practical action routed in a moral conviction. 


\section{Chapter 3: Theories of Heterotopia}

\subsection{Post-Utopia}

"This pocket of stasis within the ferment and rushing forces of social change may be thought of as a kind of enclave within which Utopian fantasy can operate. [...] But clearly, this enclave space is but a pause in the all-encompassing forward momentum of differentiation which will sweep it away altogether a few decades later."1

The Bata Utopia has become obsolete. Though it bore a unique likeness to More's Utopia, it was short-lived. It has been noted that pragmatism is one of the foundational attributes of the Bata Utopia. However, it is this same pragmatism that lead the company to reject utopias in favor of corporate survival.

With the death of Tomas Bata in an airplane crash in 1932 and the invasion of Czechoslovakia by the Nazis in 1939, the company lost both its founder and its home, and their response would put the concept of the decentralized Utopia to its greatest test. In the years following the War, the management of the dispersed Bata factory-towns endeavored to follow the founder's guidelines. But processes of differentiation (the "rushing forces of [...] change") became apparent just as the premise of industrial society itself became antiquated. By the beginning of the twenty-first century, the Bata Company's utopian origins had become a corporate liability and the company town model was abandoned entirely.

While Utopia represents a force of unification and standardization, this chapter will investigate a contrary force of estrangement and differentiation, which Michel Foucault has characterized as the Heterotopia. This study will span the conceptual and temporal gap between the height of the Industrial Utopian Project and its present condition of obsolescence.

\footnotetext{
1 Jameson 15-16
} 


\subsection{Michel Foucault: Extending the Utopian Discourse}

Michel Foucault described heterotopia as an alternate form of topos in his 1967 lecture entitled Of Other Spaces. While Utopia is a critique of common places, Heterotopia is presented as a means of critiquing Utopia itself. In this lecture, however, Foucault was in fact elaborating on the term he had used in an earlier work, Les Mots et les Choses. In both cases, heterotopias or "other spaces" are implemented as a response to the utopian discourse, but there is an apparent inconsistency in the way they are characterized in each work. The earlier description is polemical and Heterotopia is presented as the antithesis of Utopia:

"Utopias afford consolation: although they have no real locality there is nevertheless a fantastic, untroubled region in which they are able to unfold. [...] Heterotopias are disturbing, probably because they shatter or tangle common names, because they destroy syntax in advance, and not only the syntax with which we construct sentences but also that less apparent syntax which causes words and things (next to but also opposite one another) to "hang together." This is why utopias permit fables and discourse. [...] Heterotopias [...] contest the very possibility of language at its source; they dissolve our myths and sterilize the lyricism of our sentences." 2

The polemic heterotopia uses language as a means of challenging utopian presumptions -that innate links exist between signifier and signified from which meanings can be derived. When Foucault dismisses these contingent relationships as comforting fictions, he seems to position Heterotopia as an inverse, and equally unrealizable absolute. While the idea of utopia or dystopia suggests that either positive or negative rules within a place are objective, absolute and universally understood, this heterotopian theory suggests that all such connections, between words, images and things, or between individuals' interpretations of their environment, are completely subjective and unreliable. In Of Other Spaces Foucault bypasses this polemical standoff. Heterotopia is reintroduced as an extension, rather than a negation, of the utopian discourse-as the outcome of a convergence between idea and a real places.

2 Foucault - (This is Not a Pipe) 4. Quoted from Les Mots et les Choses in the translator's introduction. 
"There are also, [...] probably in all culture, in all civilization, real places, effective places, places that are written into the institution of society itself, and that are a sort of counter-emplacement, a sort of effectively realized utopia [...] I shall call them, by way of contrast to utopias, heterotopias."3

Here, Heterotopia's radical subjectivity is tempered by context. It seems that a distinction between theory and the practical outcome of heterotopias is appropriate in the same way that the Utopian Genre and Utopian Projects have been posited as related but separate entities. Yet, while Plato and More considered the idea to be the true Utopia, Foucault is concerned primarily with the practical outcome of heterotopias-it is significant to note that in Of Other Spaces the first distinction Foucault identifies between utopias and heterotopias relates to the question of material realization. Concerning utopias, he tacitly agrees with Plato and More, stating that they are "emplacements with no real place [...] fundamentally unreal spaces." He agrees that their role in society is theoretical rather than tangible. By contrast, heterotopias are estranged but real places. They are "outside all places, [but] are actually localizable." 4 This view of heterotopia can be seen in colonies, planned communities and resorts, all of which are set apart from common space by a particular defining purpose and corresponding rules of organization, conduct and admission.

The seeds of heterotopia are therefore present in Utopian Projects. While utopians pursue the arrival at and preservation of an ideal, they must assume an impossible condition of timelessness in which the vitality of the Utopia is allowed to endure undisturbed. "Heterotopology" confronts this fantasy of permanence and provides a useful framework for tracing the story of Utopian Projects over time. As these frozen, utopian moments are elongated across a timeline, the heterotopian presence is revealed in the very forces that challenge and undermine the original utopian conception. In the second, post-polemic sense, Heterotopia is a context where opposing forces exist in an ongoing dialogue.

\footnotetext{
${ }^{3}$ Dehaene \& De Cauter (Foucault) 17

4 Dehaene \& De Cauter (Foucault) 17
} 


\subsection{A Short History of Space}

Foucault's description of the "very rough history of space" traces heterotopia as a kind of subversive, dark-horse condition which confronts and opposes the more traditional utopian idealizations of space that are so prevalent in western history. From the Middle Ages to present day, Foucault characterizes this history as a process of gradual "desacralization" of space.

In medieval, preindustrial space, ${ }^{5}$ Foucault identifies a latent utopianism in the sacralized hierarchic relationships that are accepted as a natural order: sacred places and profane places, protected places and open ones, urban places and rural ones. This medieval space is the space of localized emplacements. ${ }^{6}$ In this arrangement, each place within a given locale has an imbedded meaning, purpose, and level of importance, predetermined according to its typology. These hierarchies are accepted and understood as fixed in relation to the rest of the places within the vicinity.

In the seventeenth century, Galileo initiated a key transformation in the perception of space, from localized emplacements to what Foucault calls the space of extension. Corresponding with the discovery of the Earth's orbit around the sun, the objective and fixed values associated with localized emplacements were dissolved. The old perceived stasis of the Earth at the center of the cosmos was falsified by the "opening up of infinite space," and consequently, all of the familiar localizations contained within the world, the broadest knowable emplacement, were also dislodged; "a thing's place was no longer anything but a point in its movement, just as the stability of a thing was only its movement indefinitely slowed down."7 This second spatial order introduces the heterotopian notion that the identities of places are not objectively derived from a natural order, but instead are compiled of the subjective perceptions and interpretations of individuals. The relative vantage point is an influential variable to our understanding of place.

\footnotetext{
5 Dehaene \& De Cauter 24

${ }^{6}$ This term is derived from two separate translations of Foucault's essay. Dehaene \& De Cauter translate it as "the space of localization," while Jay Miskowiec translates it as "the space of emplacement."

7 Foucault (Translation of Of Other Spaces by Jay Miskowiec)
} 
Yet the spatial perspectivism that is derived from Galileo's shift was not to be fully manifested for some time. Instead of radically altering identity or experience in the seventeenth century, the immediate impact of these scientific revelations within the space of extension was primarily theoretical, abstractly perceptual, and also infamously theological. While it became widely understood that the static positions of emplacements were "extended" into a trajectory, the everyday experience of these emplacements-their cultural meanings, their functions and their positions relative to each other and their occupants-was not fundamentally altered. Until the mid-twentieth century, it was still a space effectively conducive to utopian, localized and sacralized arrangements.

In the third and present spatial order however, which Foucault proclaimed in 1967 was already upon us, the desacralization of space has transitioned from an abstract to a literal reality. In this post-modern and post-industrial circumstance, the perceived framework that holds emplacements in fixed relation with one another is dissolved, as are the linkages between place and identity, between intent and interpretation, and between things and words. Foucault calls this the "epoch of the site," 8 but his description might be more precisely called the epoch of the dismembered site in which all places have become like the ship-located within fluid networks of interconnected points. In this desacralized or heterotopian spatial order, distinction is therefore made between emplacements of arrival and emplacements of passage. These two categories have become spatially disassociated from one another and extracted from their former localized contexts. Emplacements of arrival, or destination sites, are esteemed; giving the epoch of the site its name, they have been proliferated, enlarged, and densified. Meanwhile, the liminal and in-between spaces become increasingly marginalized and obscured both by rapid transportation between points and by the clustering, converging and overlapping of multiple destinations within a single emplacement. Whether traveling a great or small distance, one's passage through space in this era is characterized as a sequence of nearly instantaneous arrivals:

\footnotetext{
8 The term "epoch of the site" is derived from the Miskowiec translation. Dehaene \& De Cauter translate the term for this phase as "the space of emplacement" which, coincidentally, is the term Miskowiec assigns to the first phase. Despite this contradiction in terminology, both translations convey that in phase 1, "sites" or "emplacements" are fixed in real space, while in phase 3 "site" or "emplacement" refers to "positional logic of he network space." (Dehaene \& De Cauter 25)
} 
"We are in the epoch of simultaneity; of juxtaposition, of the near and the far, of the side-by-side, of the dispersed. We are at a moment when our experience of the world is less that of a great life developing through time than that of a network that connects points and intersects with its own skein."9

Accordingly, Foucault identifies the ship as the "heterotopia par excellence."10 As a person on shore perceives a ship in motion while a person on that same ship may perceive the same motion in the world beyond, the convergence of many individual perceptions of a single space yield equally numerous possible meanings and interpretations, based on the origin and focus of one's gaze. The ship at sea, "a floating piece of space, a place without a place,"11 metaphorically relates to the world's new position in the infinite space of extension. In 1972, only five years after Foucault's lecture, the metaphor of the ship was powerfully demonstrated by the first photograph of the Earth captured from outer space. In this photo, the planet appears upside down, with the south pole at the top of the image. The orientation, or relative vantage point, of the Apollo spacecraft at the moment the photo was taken, demonstrates the arbitrary and transient nature of the agreed meaning of "up."
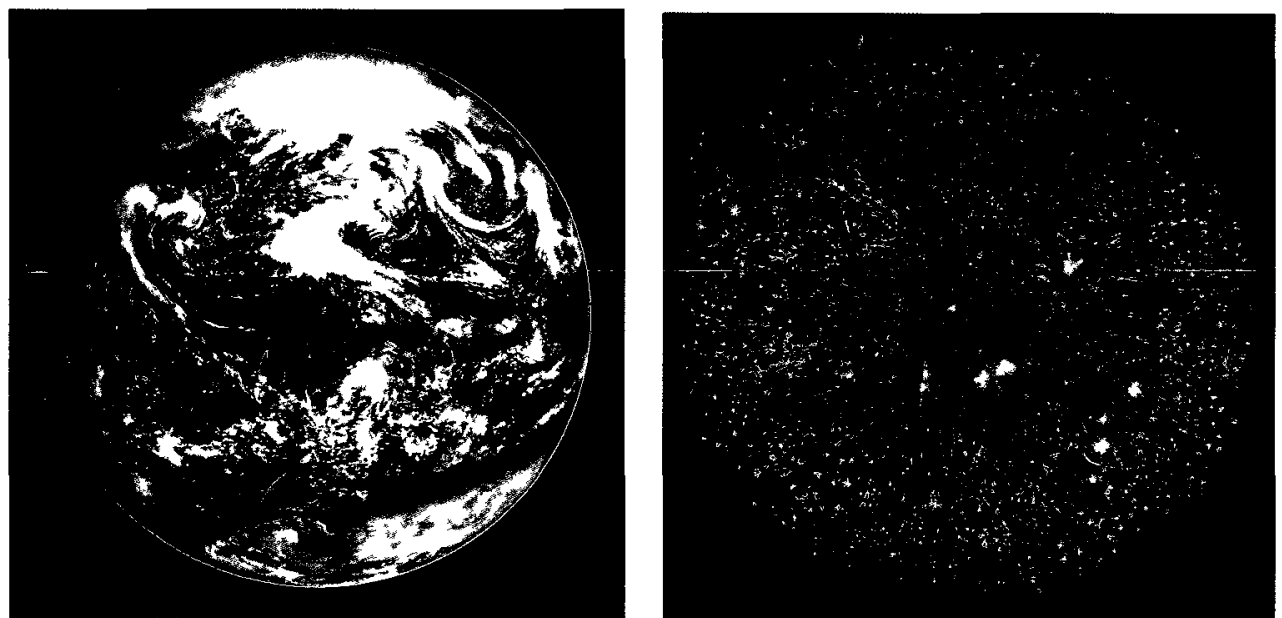

Figure 9: Two Portraits of Earth: 1) "The Blue Marble," photographed 'upside down' during the Apolo 17 lunar mission, and 2) a map of the internet by Barrett Lyon

\footnotetext{
9 Foucault (Translation of Of Other Spaces by Jay Miskowiec)

10 Dehaene \& De Cauter (Foucault) 22

11 Dehaene \& De Cauter (Foucault) 22
} 


\subsection{Network Space}

The culmination of Foucault's history of space, the epoch of the site, indicates his anticipation of the spatial paradigm of the network that emerged from the major economic and technological changes gaining momentum in the second half of the twentieth century. The Information Technology (IT) revolution, ${ }^{12}$ supplanting the industrial paradigm, represents a crucial moment in the history of space. In this era of change, the ancient human endeavors to both optimize the productive yield of space, and to overcome the dominance of distance over time were effectively realized. Two inventions developed around 1970 help to exemplify the spatial impact of IT: the microprocessor, or "the computer on a chip," revolutionized the field of electronics and radically reconstituted the minimum scale of productive space. Meanwhile, building on the spatial impact of the telephone, radio, television and of increasingly rapid means of physical transportation, the American development of a decentralized electronic communications network during the Cold War, which eventually became the internet, introduced unprecedented, virtual linkages between dispersed locales. ${ }^{13}$

These innovations form the technological backbone of the information age and they have facilitated a spatial arrangement in which one's localized position and the amount of space one occupies in a network is not strictly related to production capacity in advanced services. ${ }^{14}$ Yet while the "structural logic" of the information age is placeless, ${ }^{15}$ over forty years of network space has demonstrated that the importance of fixed places has not been overcome, but rather has increased. The physical infrastructure of networks in the information age relates to specific places "very much like railways defined "economic regions" and "national markets" in the industrial economy."16

\footnotetext{
12 Castells 41

${ }^{13}$ Castells 44

${ }^{14}$ Castells 378

15 Castells 413

${ }^{16}$ Castells 412
} 
However, the role of these localized places has been inverted, from a container of activity to a conduit. Industrial utopias are localized, closed loops in which management, production and consumption were more or less contained within spatial boundaries. Conversely, in network space, localized sites function as hubs through which global "flows" of information, capital, management, services, and goods are channeled. ${ }^{17}$ These hubs relate to each other hierarchically as much as geographically; although places are fixed relative to one another, the fluctuating and ephemeral flows that pass through them are perpetually reconstituting their "position" in the network. It is in the intersection between place and process-these coexisting "spaces" that are fundamentally irreducible to one another-that network space truly registers as heterotopian.

\subsection{The Sovereign Citizen}

Foucault's formulation of heterotopia opened up a new area of discourse through which all facets of the utopian project can be critiqued: social, economic, spatial, formal and so on. Heterotopology is not only a threshold between spatial and technological paradigms, it coincides with, and indeed participates in, the critical shift from industrialism to postindustrialism and from modernism to post-modernism. Foucault's essay is a product of a culture that is eager to reinvent itself. As a result, the introduction of heterotopia could be seen as the moment that effectively marks the end of both utopian discourse and utopian projects in the twentieth century.

One of the motives underlying this desire for emancipation from utopia was emotional. Utopian Projects had earned a "bad rap" due to the reductive, totalitarian programs of Stalinism and Nazism.. The recent memories of such potent failures of utopian ideologies came to be seen as the inevitable outcome of utopian action, that "neglected human frailty and [...] betrayed a will to uniformity and ideal purity [...] that always had to be imposed by force." 18

Another reason for the dissolution of the Utopian Project was more practical. In the increasingly globalized economic network, local "pockets of stasis" became antiquated.

\footnotetext{
17 Castells 412

${ }^{18}$ Sorkin 6, Jameson xi
} 
While utopias can accommodate a measure of technical progress within themselves, they are confined by a prescribed premise and method of practice. For most Utopian Projects of the twentieth century this premise was found in the precondition of industry; the oppressive mechanized forces of the nineteenth century mobilized a movement of practitioners who sought to reinvent industrial space into an environment where justice was expressed through optimal efficiency. The benevolence that later became one of the legacies of welfare capitalists such as Ford and Bata, was also shrewd business since it recognized the direct correlation between the well-being of the workers and productivity.

Information technology has facilitated a new phase in the capitalist pursuit of efficiency and has prompted a massive worldwide restructuring of capitalism. ${ }^{19}$ it was found that the yield of space and capital could be dramatically increased by fragmenting the industrial utopia and redistributing its parts to distant sites spread across the global network. This new arrangement largely circumvents the added cost and responsibility associated with maintaining an enclosed and self-sustaining ecosystem and a culturally engaged laborer. In short, the industrial utopian enclave has become obsolete:

"Fordism had embedded within it the seeds of its own undoing. The breaking down of the assembly process into smaller and smaller tasks, combined with rapid advances in transportation and communication, made it easier for manufacturers to break out of the dependent relationship established by Ford between high wages and large markets. Goods could be made in one place and sold somewhere else, removing the incentive employers had to pay workers enough to buy the products they made. [...] The economy that in Ford's mind operated as a symbiotic whole-land, labour, resources, manufacturing, finance, and consumption-were drifting apart." 20

At the core of this dispersal is a radical shift in the social and economic identity of the individual. Through the works of Plato and More, individual identities and competing notions of wholeness-civic, familial or personal-are dissolved and reoriented to an

\footnotetext{
${ }^{19}$ Castells 13

${ }^{20}$ Grandin 74-75
} 
ultimate identity as a utopian citizen. In the industrial utopia, this dominant vertical relationship is manifested in the sole dependence of each worker on the company to sustain every aspect of life. In company towns, therefore, residents are provided with subsidized living space, recreation space, production space and consumption space. Horizontal relationships between peers, outside of the company's jurisdiction are deemphasized and individuals are enticed to remain content and dispersed. This antirevolutionary sentiment is evident in Ford's high-wage practice and in his well-known opposition to worker unions. Similarly, Tomas Bata proclaimed a motto "work collectively, live individually," that was formalized in the spatial arrangement of Bata towns by his strong preference for detached family dwellings; utopian citizen were subtly but routinely discouraged from congregating outside of the factories.

By contrast, in heterotopian space, the individual is empowered with a new sovereignty to constitute personal ideals, and with a mobility to pursue the realization of them. This arrangement stands in contrast to utopian space since it facilitates horizontal relationships among individuals with varied but overlapping motives, interests and abilities. The infinite possible outcomes of these convergences cannot be foreseen, controlled or scripted by a central source. ${ }^{21}$ The sovereign individual as consumer, or as inventor or as entrepreneur, is empowered in network space by a nearly instantaneous accessibility to desired destination sites, either virtual or real. Through the limitless potential opened up by this autonomy and mobility, utopian idealization has been repurposed as a personalized pursuit, accommodating one's own preference and desire rather than collective values. The individual has replaced the community as the new unit of wholeness and the new site of utopian investment. Each person's motivation becomes a private utopian ideology and the means by which one pursues such desires similarly becomes a private utopian practice. While Utopian Projects have appeared only sporadically in history, when economic and social circumstances are conducive to their program, ${ }^{22}$ the late twentieth century has revealed a "utopian impulse" which thrives at the scale of the individual while the full-scale communal iterations appear absent.

\footnotetext{
21 Castells 6

22 Jameson 10, 37
} 
"Utopian corporeality [...] invests even the most subordinate and shamefaced products of everyday life, such as aspirins, laxatives and deodorants, organ transplants and plastic surgery, all harboring muted promises of a transfigured body, [...] sewn like a red thread through our practices of consumption."23

\subsection{From Infinite Semiosis to Context}

The empowered individual-what Nietzsche calls Übermensch or Super Mancharacterizes what Foucault was responding to when he described the heterotopia as the total disruption of language, syntax and meaning. It was not through suppression that the Utopian Project was undermined, but conversely, as Nietzsche anticipated, through the infinite diffusion of Utopus' authority to all individuals. As a consequence, in what Jameson calls "post-civil" society, ${ }^{24}$ people have become isolated within personal paradigms, between which language and representation cannot be relied upon to convey intended meanings. The mutual incompatibility between utopian variants that was first seen among writers of the Utopian Genre, has been radically diffused into the heterotopian social arrangement.

Yet in spite of his own implications to the contrary, Foucault recognizes that this condition is not absolute. Amid the "rubble of signifiers," ${ }^{25}$ practical sacralizations, or shared frameworks, agreements and understandings, still endure:

"Our life is still ruled by a certain number of oppositions that cannot be touched, that institution and practice have not yet dared to undermine; oppositions that we regard as simple givens: for example, between private space and public space, between family space and social space, between cultural space and useful space, between the space of leisure and that of work. All these are animated by an unspoken sacralization." 26

\footnotetext{
23 Jameson 6

24 Dehaene \& De Cauter 3

${ }^{25}$ Henket \& Heynem 12

${ }^{26}$ Dehaene \& De Cauter (Foucault) 16
} 
Umberto Eco's parallel study of semiosis in texts offers insight into the endurance of these spatial sacralizations. Against the radical perspectivist, or "reader-oriented" position, which asserts that an infinite number of equally valid interpretations can be derived from a single source, Eco contends that in the dialectic between the ambiguous intentions of the author and the potentially infinite intentions of interpreters, there is also the intention of the text itself. 27 The specificity of a text's temporal and cultural origin, and the specificity of the words it contains, endows it with a contextual anchor which limits its plausible meanings to the finite, and allows for such a thing as a good interpretation and a bad one. "I accept the statement that a text can have many senses. I refuse the statement that a text can have every sense."28 In light of these analyses, even within "desacralized" heterotopian space, their are limits to the sovereignty of the individual just as the preceding utopian industrialists were also unable to fully attain Utopus' majesty.

At the outset of the thesis, I theorized that heterotopia is the compositional opposite of utopia. While the utopian pole assumes a perfect collective adherence to a set of universally understood principals, the heterotopian pole conversely suggest that any such understandings are universally impossible. In other words, any presumed understanding is built on the faulty premise that language is innately linked to that which it references. "As soon as a [...] meaning is allegedly discovered, we are sure that it is not the real one; the real one is the further one and so on and so forth; the [...] losers are those who end the process by saying 'I understood."'29

Through the subsequent study that followed this polemic reading of heterotopia, it seems that, despite an initial trajectory towards total perspectivism, placelessness and infinite semiosis, heterotopian space becomes useful as an expression of real contexts. The idea of a place without any sacralization is as removed from real context as the idea of a place without any variety, and therefore is not heterotopian but ou-topian. Heterotopias, rather, are situated in the real space between the unreachable extents of ou-topia (the

\footnotetext{
27 Eco 25

28 Eco 141

${ }^{29}$ Eco 39
} 
non-place) and eu-topia, (the good place). ${ }^{30}$ In this space, both poles participate but neither can dominate entirely.

30 Hetherington viii 


\subsection{Towards a New Heterotopian Architecture}

This thesis has been an investigation of two particular spatial paradigms, and of their influence on real space and practice. My study is broken down categorically into four distinct areas of discourse: utopian theory and utopian practice, heterotopian theory and heterotopian practice. The first three chapters have accordingly confronted the first three of these categories, largely leaving the question of heterotopian practice still to be addressed. This discussion has not only been left to the final chapter for reasons of chronology, but also because I will conclude the thesis by proposing a heterotopian methodology and architectural project.

When the spatial theory of heterotopia was introduced, it was eagerly received by architects as a validation of the growing critique against utopianism and modernism, whose sacralizations had become regarded as oppressive, tyrannical, and disconnected from the real lives and desires of people. Heterotopia was thus championed as a means of advancing postmodernism. ${ }^{1} \quad$ Today, both the modernist and postmodernist architectural movements can be viewed and analyzed retrospectively. There is no longer the same urgency for a conceptual device with which to overthrow the prevailing paradigm. I argue, therefore, that at this moment in the history of space, the re-reading of heterotopia will yield an alternate set of potentials which may not have been recognized in the context of postmodernism; namely, that a heterotopia does not necessarily displace or preclude the modernist inclination towards utopia. Heterotopias need not be synonymous with the fragmentation, the radical individuality, and the nihilism with which postmodernism is now often associated, ${ }^{2}$ though it is not entirely separate from this inclination either. Instead, heterotopia is a context in which such contradictory conditions may coexist in a responsive and self-critical manner. These conditions, each of which is somewhat dysfunctional in isolation, can be redeemed through their convergence. In his paper, Eutopia Now!, Michael Sorkin similarly

\footnotetext{
1 Dehaene \& De Cauter (Sohn) 47

2 Henket \& Heynem 12
} 
suggests an alternate, or "heterotopic" reading of utopia, as the premise of his own architectural project:

"the fantasy of a single point of formal convergence must be trashed in favor of an inexhaustible multitude of non-homogeneous outcomes. [...] The necessary singularity of any utopian image will be alleviated by multiplicity-every utopia adds to the repertoire of urban possibilities. [...] As a representation, the Modernist utopia may have depicted the annihilation of variety, but as an artifact in context, it was an addition to the reservoir of possibilities for the urban form of the city."3

Unfortunately, the project that Sorkin develops seems to narrow again into another new utopian polemic founded on the current moral imperative of environmentalism and sustainability. However, he recognizes that utopias can be made adaptable if their internal mechanism for repelling all other variations and expressions of places can be circumvented, allowing them to cohabit in real space. This points back to Foucault's post-polemic heterotopia, or "effectively realized utopia," as a context which sustains discourse between contrary entities. Heterotopology describes an intersection between a place and a process; ${ }^{*}$ it outlines the criteria through which anomalous locales can be identified and described, and it traces the various forces of differentiation which alter the site over time. The question of how to intervene on such a site-to partner with the processes of change rather than ending them-is an important challenge for architects, requiring the investigation of a site's physical and temporal context.

With these considerations I engage the heterotopia of the company town. These defunct Utopian Projects are rapidly being shut off and disconnected from the "flows" that sustain the globalized network of places. These sites, which were a fixture of the modernist industrial era, have proven rigid and ill-suited to adapt to the new paradigm. For my project of architecture I will return to the test case of the Bata Utopia and its factory town of Batawa, Ontario. I will develop what I contend is a heterotopian methodology, towards a heterotopian outcome.

${ }^{3}$ Sorkin $9,10,16$ 


\subsection{Batawa}

The small town of Batawa is located in southern Ontario, along the banks of the Trent River. It is a well-maintained community consisting of about one hundred houses, mainly detached 1970s era bungalows, divided between two small neighborhoods. There is a church, a school, a legion hall, a ski hill and chalet, and a community centre. In most respects it appears to be a typical bedroom community to one of its nearby cities. There is however, an unmistakable indication of an alternate identity the nowabandoned Batawa Shoe Factory. While this five level concrete frame building, clad in pealing white metal siding, appears massive and out-of-place in this rural environment, it is the reason for the town's existence. On the factory's water tower, perched above its roof, you can still make out the faded word Bata.

Batawa was founded in 1939 as one of the company's many independent factory towns around the world. It was established by Thomas Bata Jr., son of the company's founder, and approximately one hundred of the company's employee families, who had quickly immigrated from Czechoslovakia in anticipation of an impending Nazi occupation of their homeland, and hometown of Zlin. By the next year, construction of the Batawa factory and of the worker housing was well underway and by 1941 the town was fully operational.

Conceived as the New Zlin, Batawa eventually became one of the company's production headquarters. While much of the planned construction was never executed, what was built in its early years unmistakably belonged to the Bata tradition of architecture and planning. It had small detached square homes-Canadian wartime houses-arranged in the typical Bata checkerboard pattern. The factory not only reflected both the design specifications and construction techniques of its Zlin counterparts, but also much of the necessary materials, formworks and cranes were actually imported from Zlin as well. ${ }^{4}$ It is constructed in the typical $6.15 \times 6.15$ meter reinforced concrete module, three bays in width and thirteen in length with the characteristic projections for the vertical circulation. At the center of the roof was placed the factory's water tower: a single extruded boxthe Bata module-iconically presiding over the town on a pedestal of four concrete columns.

\footnotetext{
${ }^{4}$ Ricketts
} 
Over the course of its seventy year history, Batawa has undergone numerous physical changes which have corresponded to its cultural, social and economic story. Through the 1950s and 60s various other facilities were built which reflected the company's new home in Canada, and departed from Zlin's distinct architectural language. These including a bank and a community center built in 1963 by Toronto modernist architect John Parkin. In the 1970s, the original company-owned worker houses were replaced when the lots were sold to their occupants: another significant alteration to the original company town model.

Batawa's most telling architectural transformations, however, have occurred in the Shoe Factory. Several additions were constructed to adapt to changing production needs, and in the 1980s a dramatic re-cladding of the building took place due to poor thermal performance of the glazed walls in the Canadian climate. This regional adaptation of an International Style building involved replacing the expansive glazing with insulated infill walls with only a thin horizontal band of windows on each level. The traditional Zlin Style aesthetic-red brick, white concrete and generous glazing-has been concealed in white aluminum siding. The final transformation to the factory came in the late $1990 \mathrm{~s}$ when shoe production ended in Batawa. What had been the community's source of economy and employment now stands empty and unused.

The Bata Shoe Factory has always been linked to Batawa's vitality, as a symbol of the Bata lineage, as a unifying force in the community, and as an economic generator. Even in its current state of disuse, this architectural artifact retains both cultural and practical value. It is historically significant, as an anomalous instance of refined, interwar European modernism in Canada, while a recent engineering assessment has found it to be well-built and structurally sound. Its characteristic open plan makes it adaptable to many potential uses which could bring life back to the town. Because of its central role in Batawa's identity and in light of its (hidden) charm, the factory is a ideally suited to be the origin of the town's rebirth. 


\subsection{BIM as a Heterotopian Method}

A building is never frozen in time. Outside of the imagination, the mind's eye, or other utopian fictions, a single building's story parallels that of its environment, its builders and its users. Batawa's most iconic building, the Bata Shoe Factory, is a living document that has been imprinted by each phase of the town's story: from its conception as an industrial utopia, through its subsequent adaptations to local economic, social and climatic conditions, to its eventual decline. This thesis endeavors to integrate the Factory's temporal and cultural context into the database that will inform a proposal for its rehabilitation.

To achieve this, I have constructed a Building Information Model ${ }^{5}$ of the factory. BIM is a category of digital applications for design and construction management that represents a new paradigm of architectural representation. It is rapidly becoming the new industry standard in contemporary practice. It replaces conventional drawing sets with a consolidated database containing all of the quantitative information relating to a project: material, structural, mechanical, electrical, programmatic and so on. A BIM can generate a building's plans, sections, elevations, detail drawings, and material schedules from a single three-dimensional digital model, while any individual element within the model can be extracted, viewed and modified independently.

There is a utopian quality to the BIM paradigm. As with previous methods of architectural representation, it is a numerically exact, idealized construction, akin to the idea of a building rather than a realizable approximation. Moreover, as a practical all-inone tool for architectural production, the BIM workflow is also a kind of totality; when a single drawing within a BIM is altered, the change is automatically reflected throughout the Model-everything in its proper place. Within a single interface, the building can be viewed at any scale, from its overall form to its most minute detail. However, like real buildings, a BIM is not frozen in time. It is a uniquely living document which allows for a single Model to simultaneously exist at multiple moments in the building's history. This "phasing" tool, which in professional practice is used for coordinating construction timelines, has been appropriated in the Bata Factory Model as a way to document it at

\footnotetext{
5 The specific BIM software I am using, and to which I refer when speaking of specific features, is Autodesk's Revit Architecture.
} 
distinct points in its history. This tool provides a way to reconstruct the factory's temporal context-the story of its passage through time. A BIM can also host other time-bound investigations such as building performance analyses and future design studies. Its use does not end upon the completion of the real building's construction. A BIM is designed to be easily updated to reflect subsequent alterations and proposals to the building it represents. Like a museum or a library, a BIM database is a heterotopia; a context of "infinite accumulation" 6 in which contrasting elements cohabit. Through the process of constructing this model, I have questioned what seem to be the boundaries of "building information" that can be accumulated within a BIM. I have endeavored to expand these boundaries to include qualitative cultural information, such as historic photographs and drawings, to augment the Model's tectonic information with intangible moments from the building's past. Conceivably this intangible category could be expanded much further to include information such as personal accounts of people who participated in the building's story, to unrealized architectural proposals that have been made.

If BIM databases continue to expand with both quantitative and qualitative building information, the importance of "good" interpretation among those assembling and using the database will also grow. Each fragment of information accumulated within a Model adds specificity to the context in which the building is interpreted. Aside from its benefit as a unique cultural heritage document, this expanded BIM can provide an unprecedented tool for architectural invention where past realities, alternate realities and the current reality are co-present and can directly inform future proposals.

\footnotetext{
${ }^{6}$ Dehaene \& De Cauter (Foucault) 20 - Seen in the fourth principal of heterotopias
} 

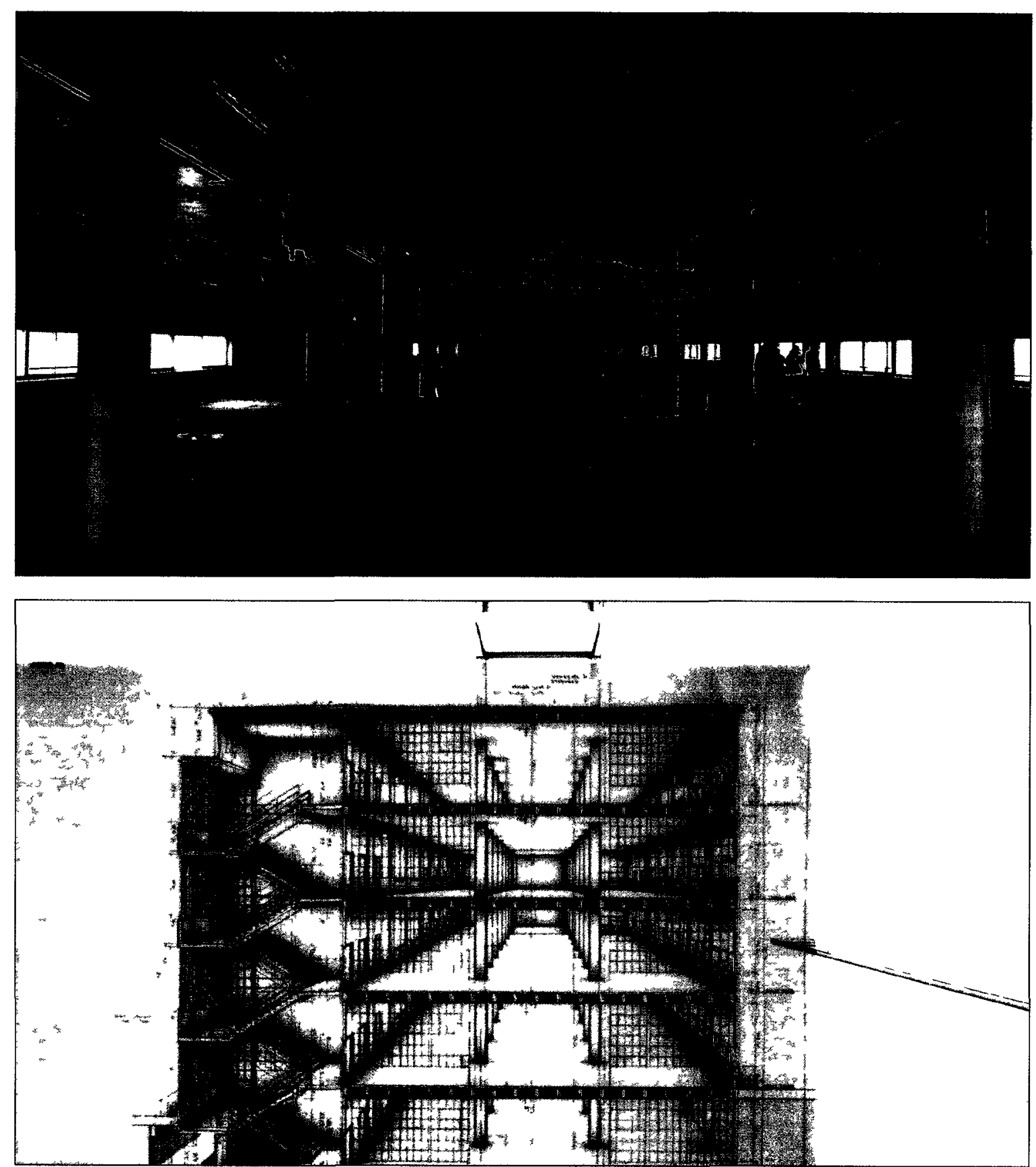

Figure 10 Photo of Batawa Shoe Factory interior "Home Statıon"

Figure 11 Sectional view of Bulding Information Model of the Batawa factory 


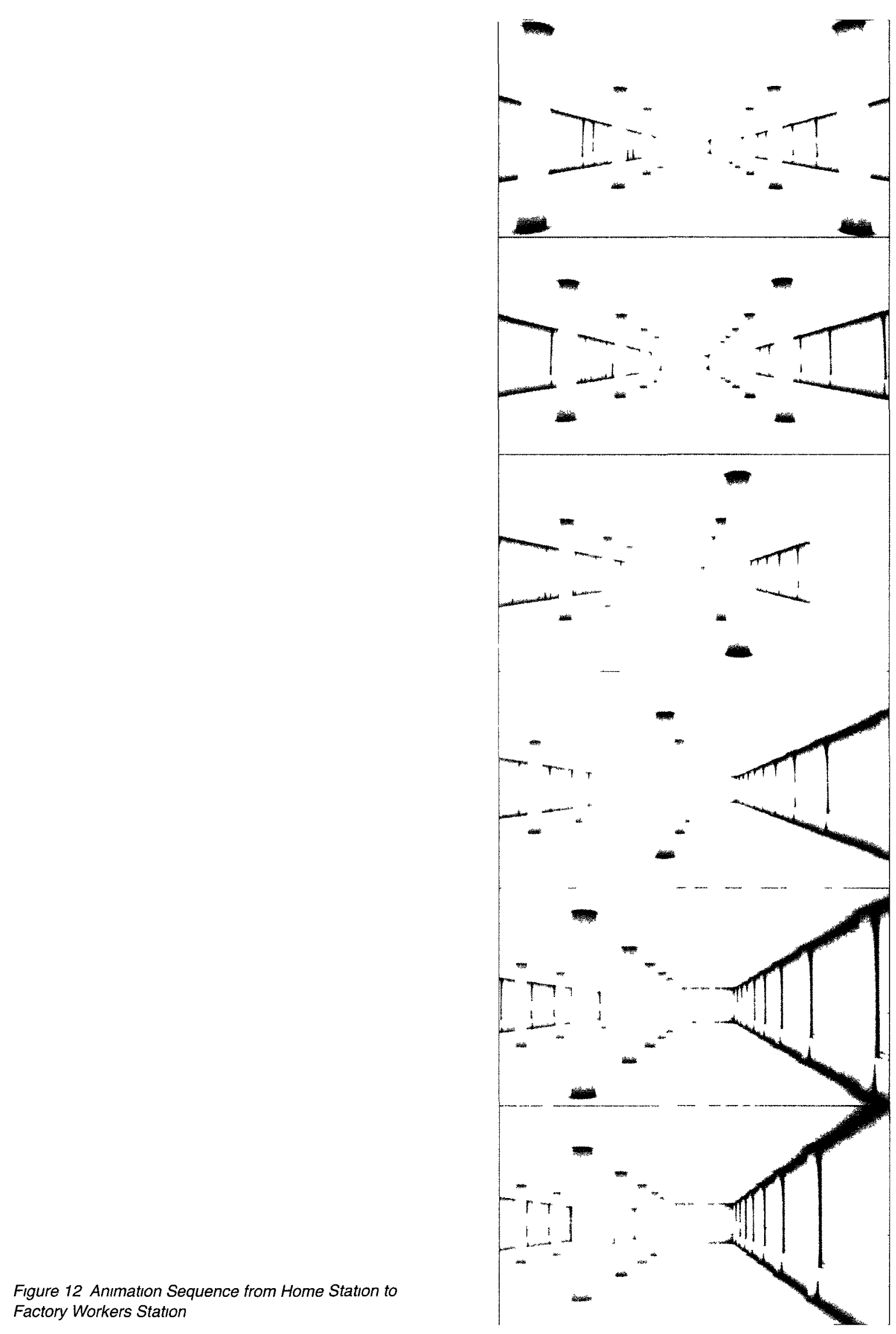




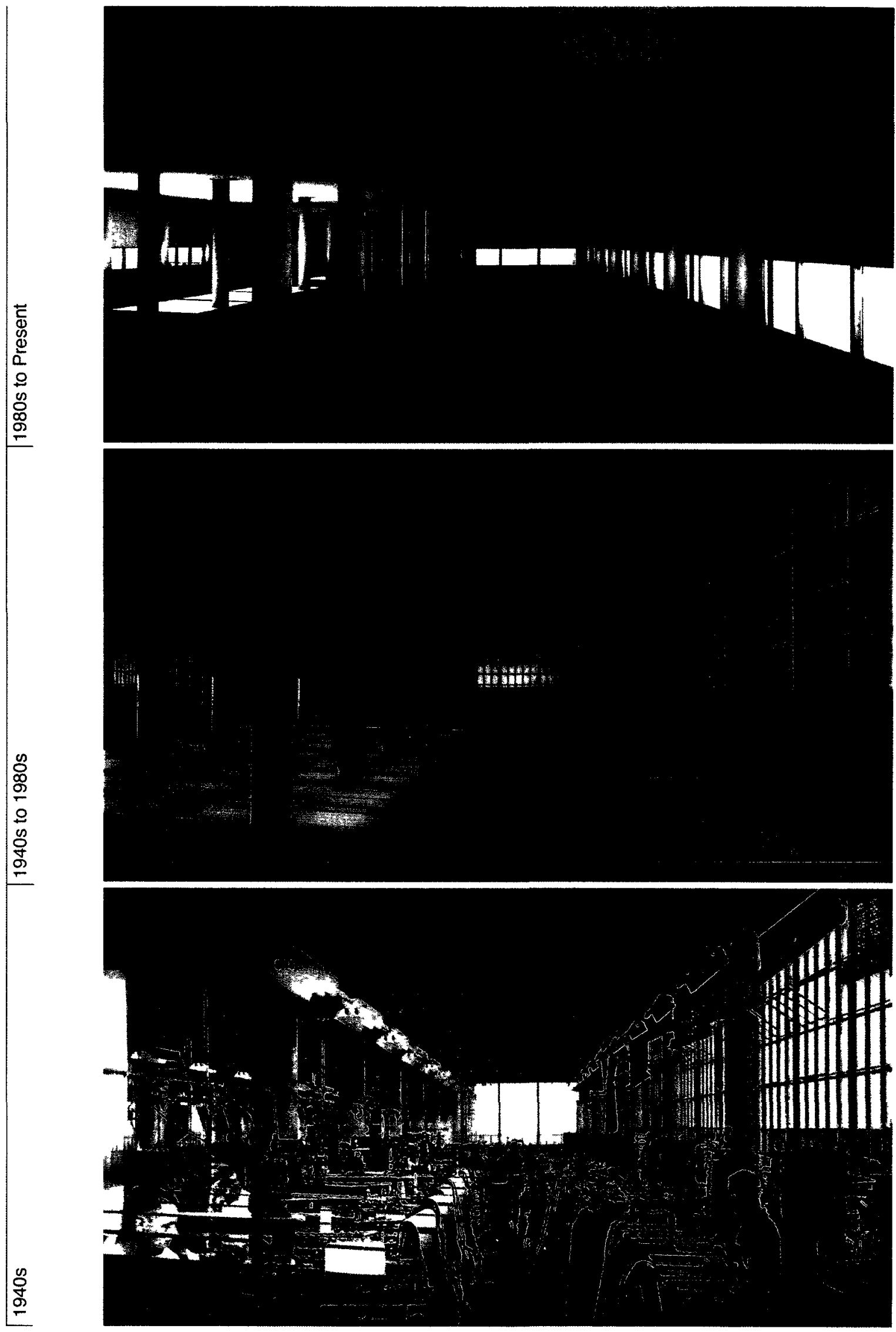

Figure 13 Temporal Sequence at Factory Workers Station 

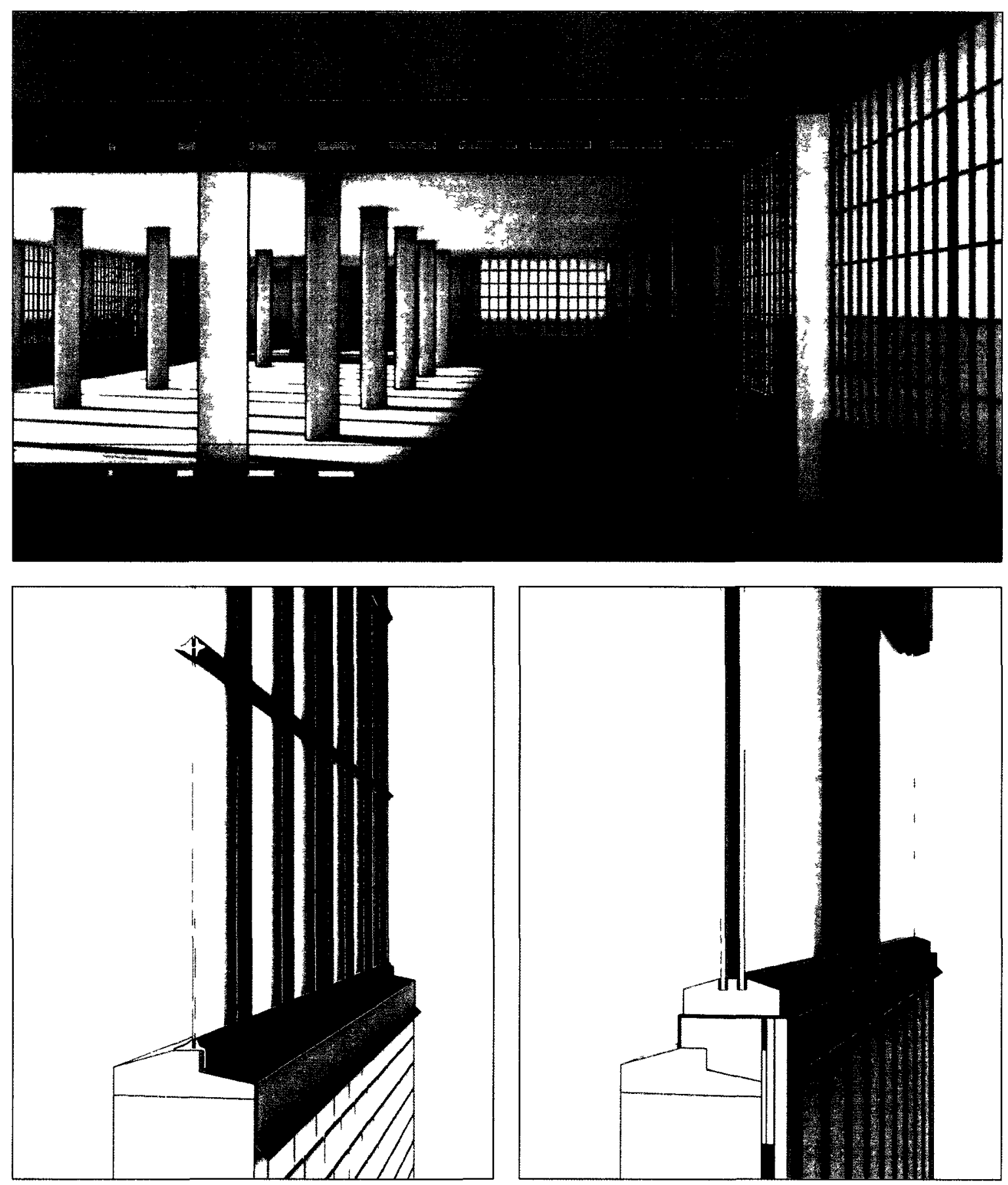

Figure 14 Section Detalls 


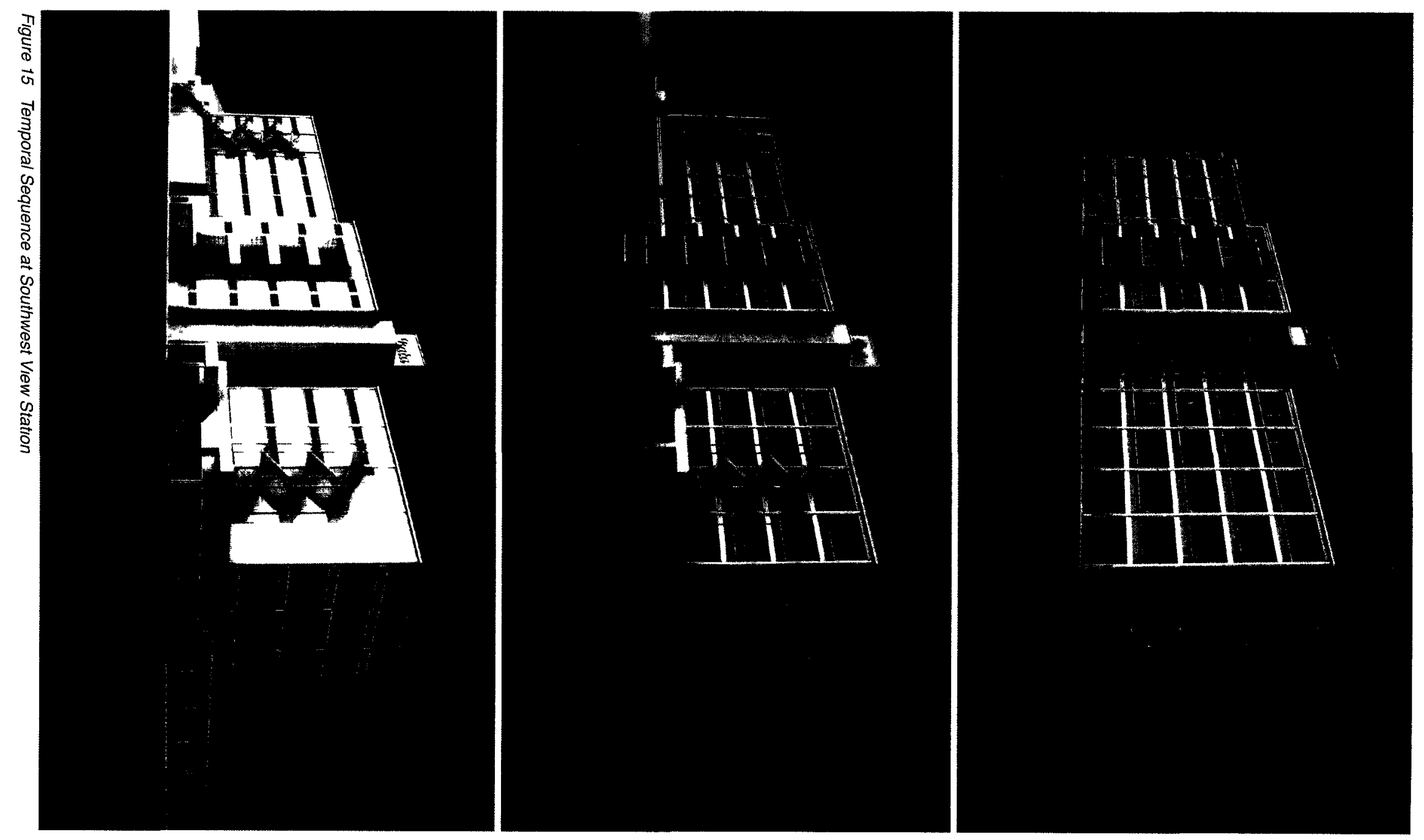




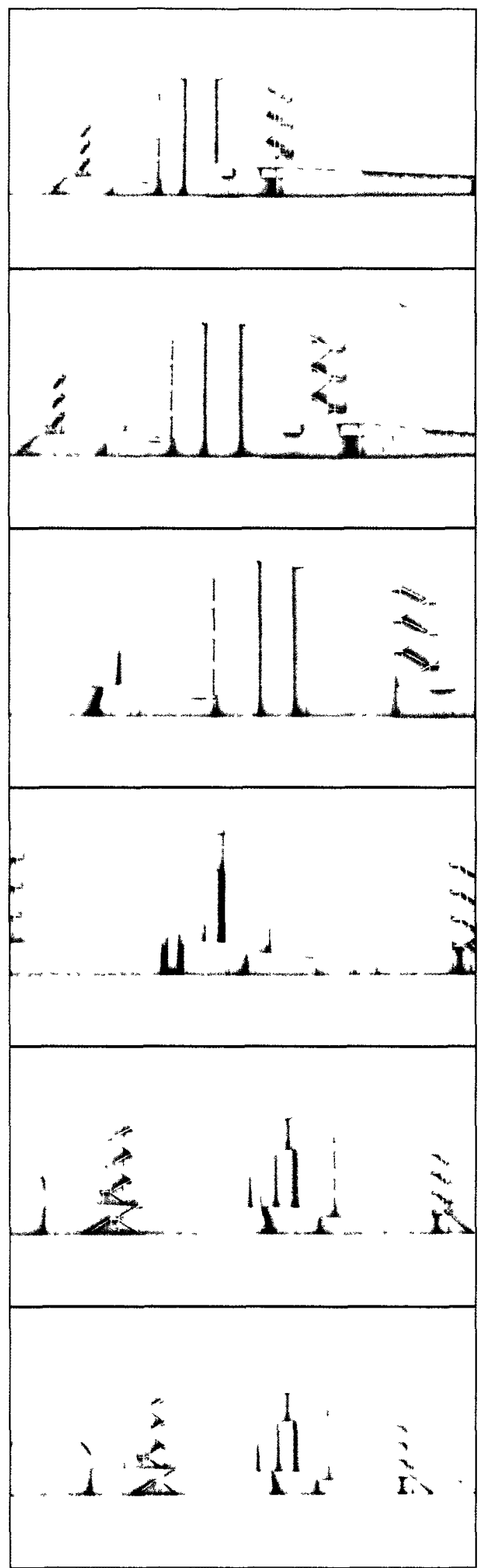

Figure 16: Animation Sequence from Southwest to Northwest 

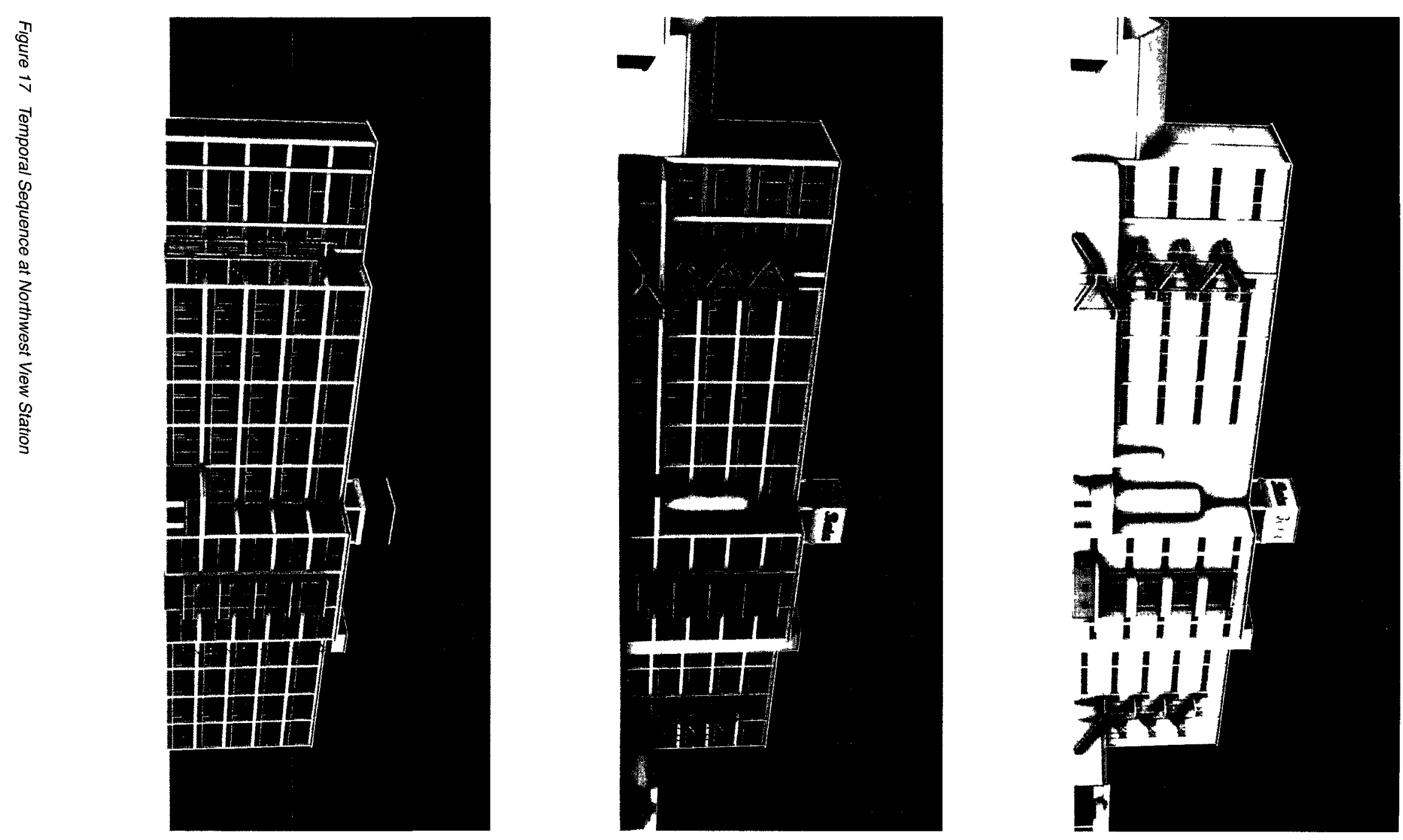


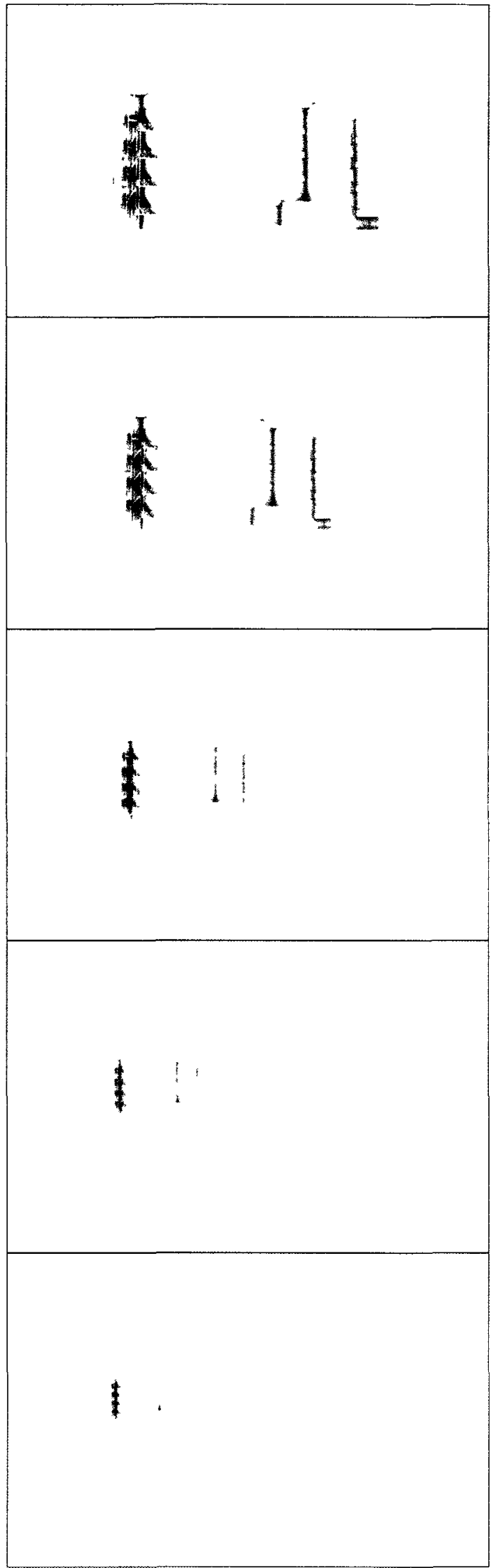

Figure 18: Anımation Sequence from Northwest View Station to Fraser Drive View Station. 


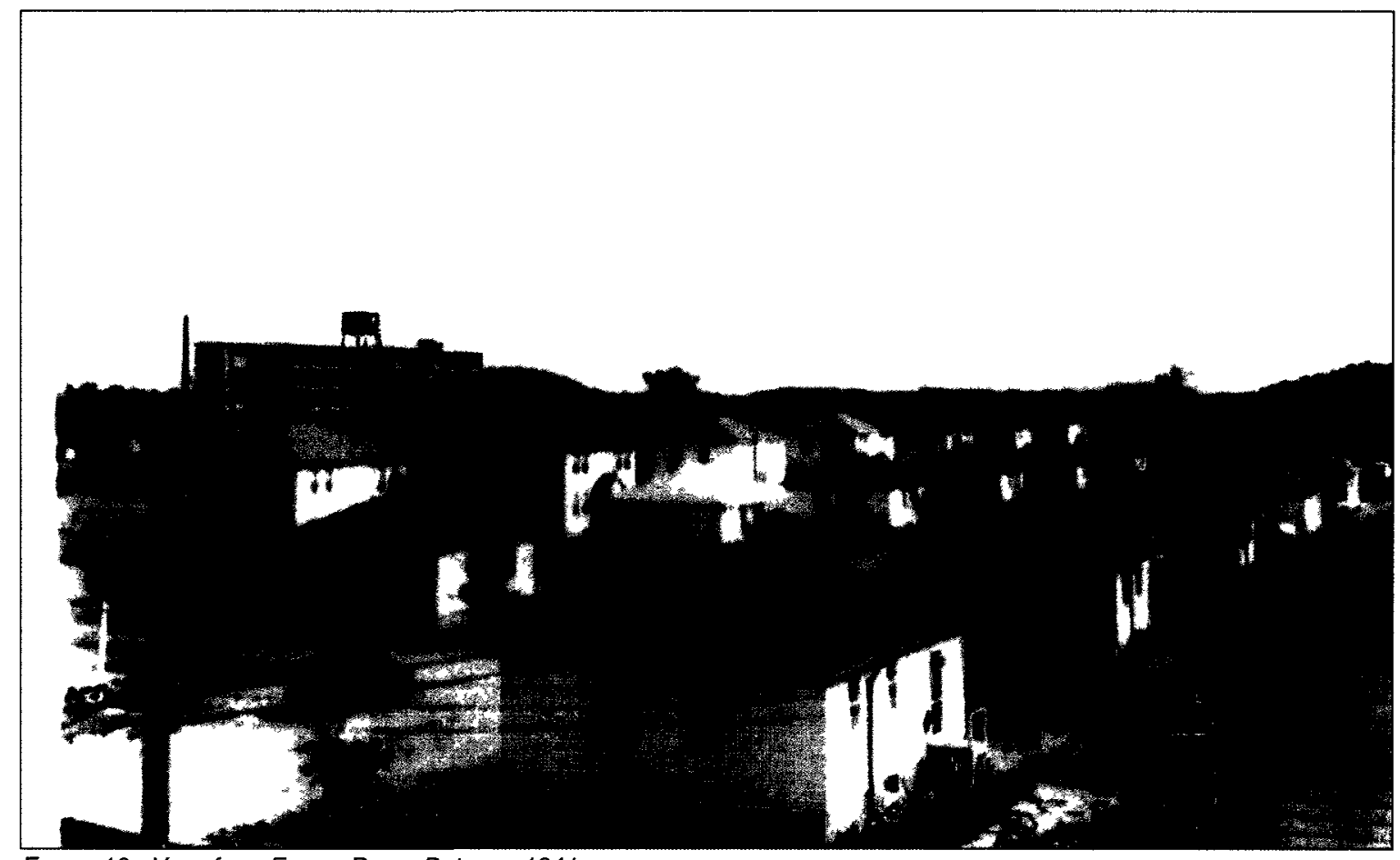

Figure 19 View from Fraser Drive, Batawa, 1941 


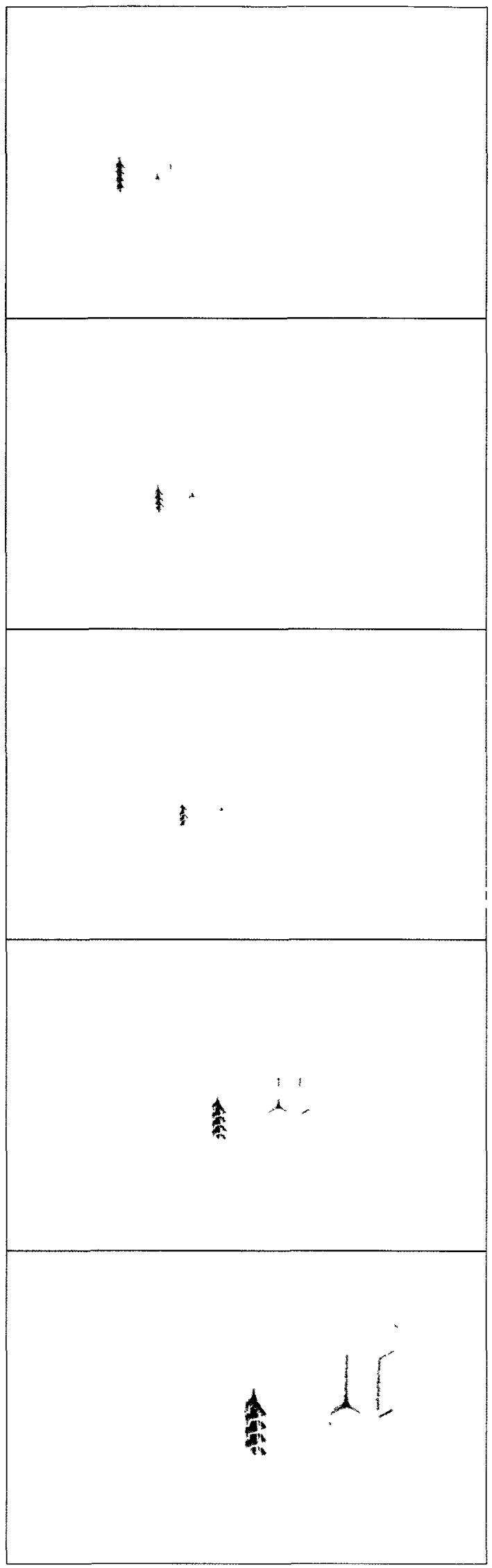

Figure 20: Animation Sequence from Fraser Drive to Axonometric View Station 

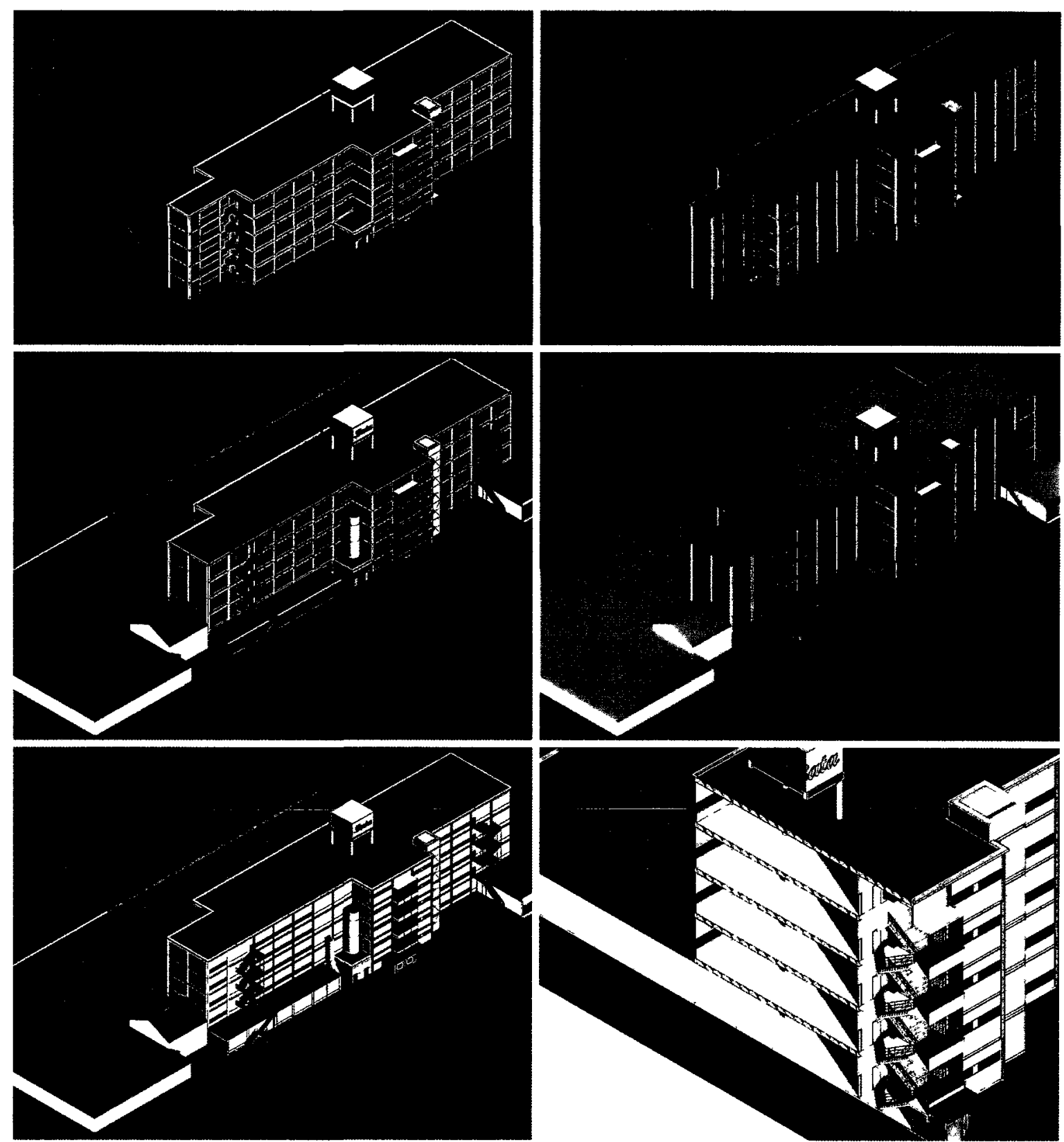

Figure 21 Temporal Sequence at Axonometric View Station Red highlights identify the objects which are changed from one phase to the next 


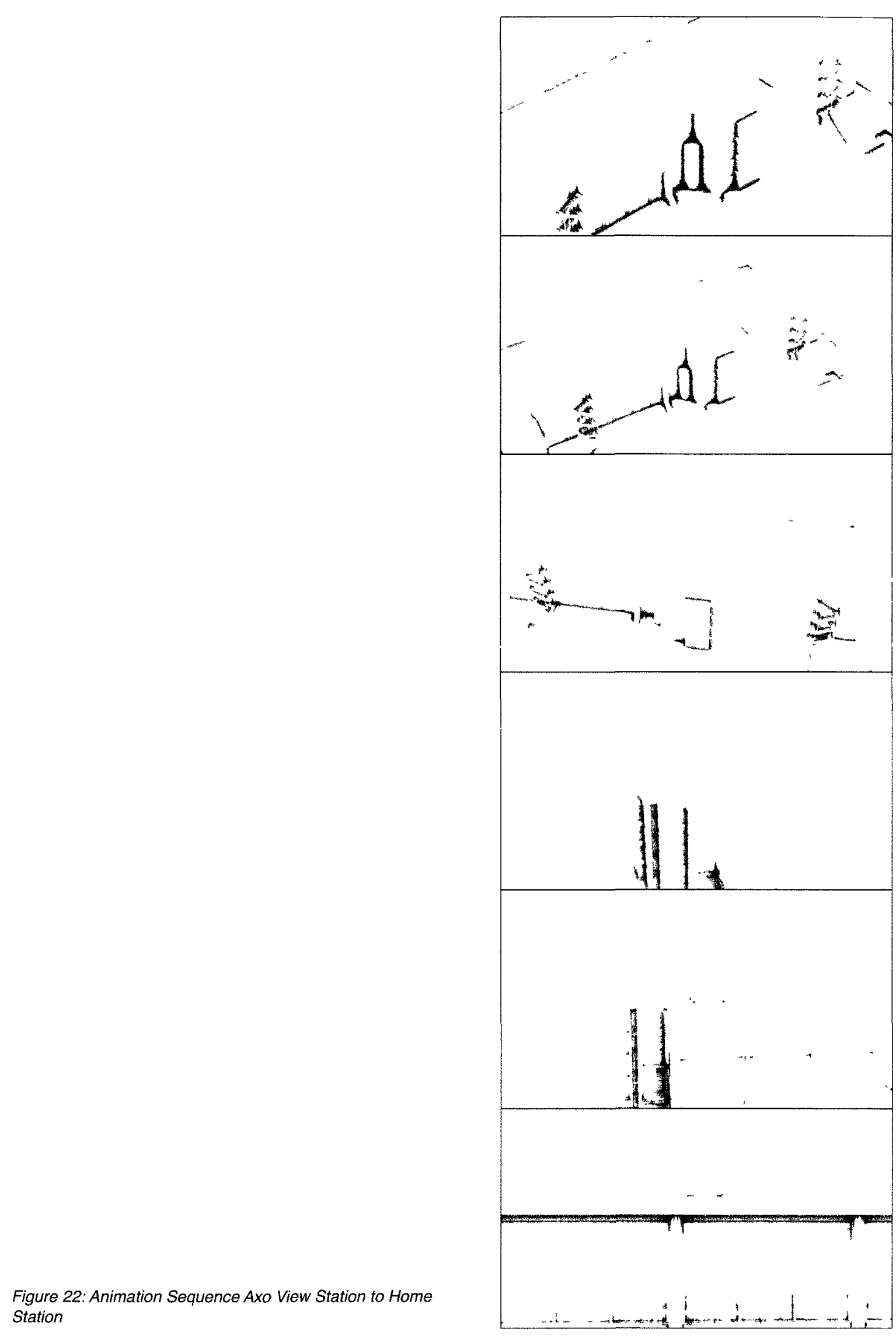




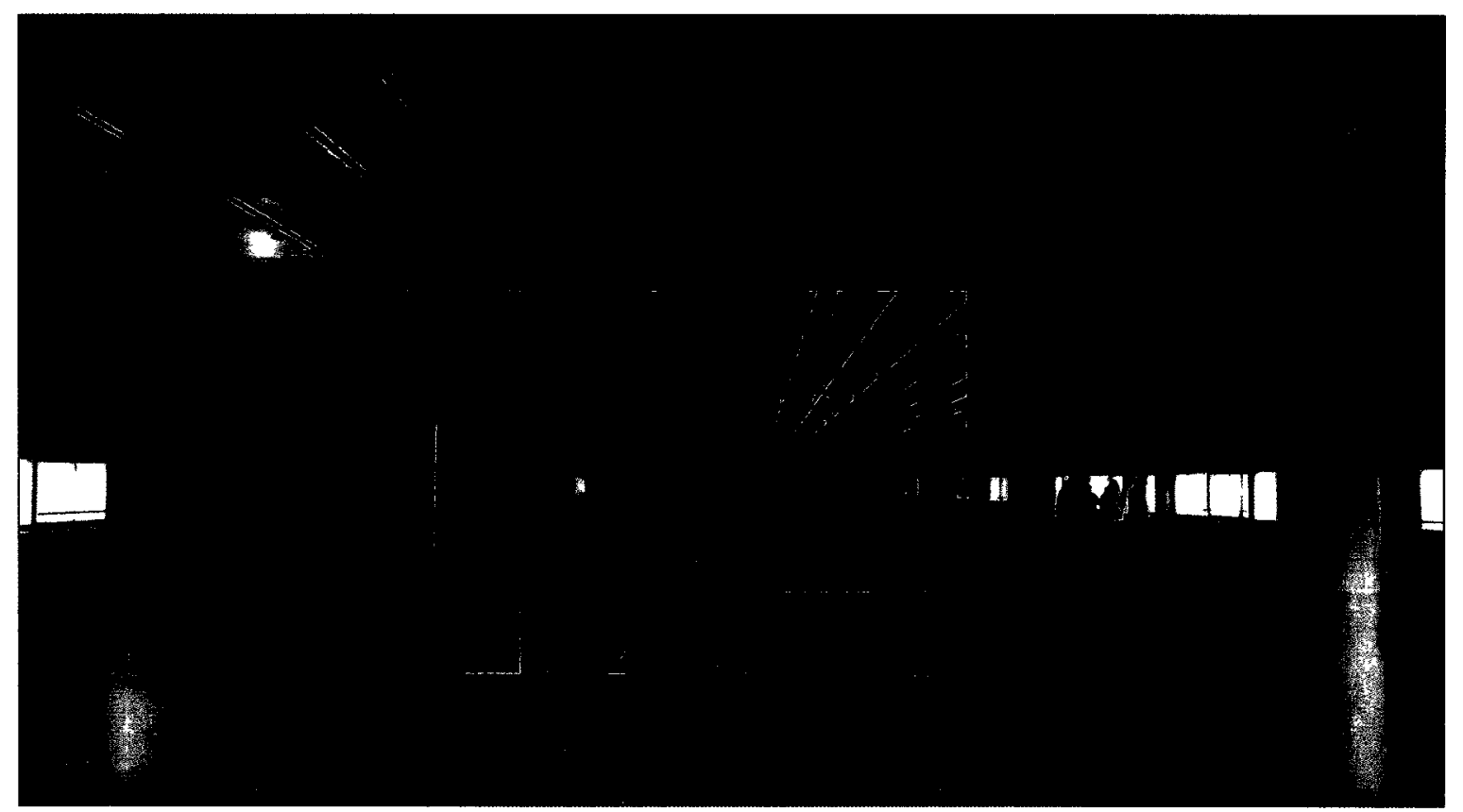

Figure 23: Home Station Composite. 


\subsection{Project as Dialogue}

One of the primary challenges any architectural project in Batawa must address is to reintroduce economic and social vitality to the community. Since the departure of factory production, most of the town's remaining population of around three-hundred people must travel to neighboring communities for everything from employment to groceries. In 2005, Sonja Bata, wife of Batawa's late founder, established the Batawa Development Corporation to undertake the renewal of the town into a model, "green" community of the twenty-first century. Among the Corporation's stated goals is to increase the town's population to 1500 within the next ten years, while attracting commercial, light industrial and live-work economic development. ${ }^{7}$ At the center of this vision of renewal, the Factory would be converted into a seventy-five unit condominium building and would be returned to its red-brick and glass aesthetic.

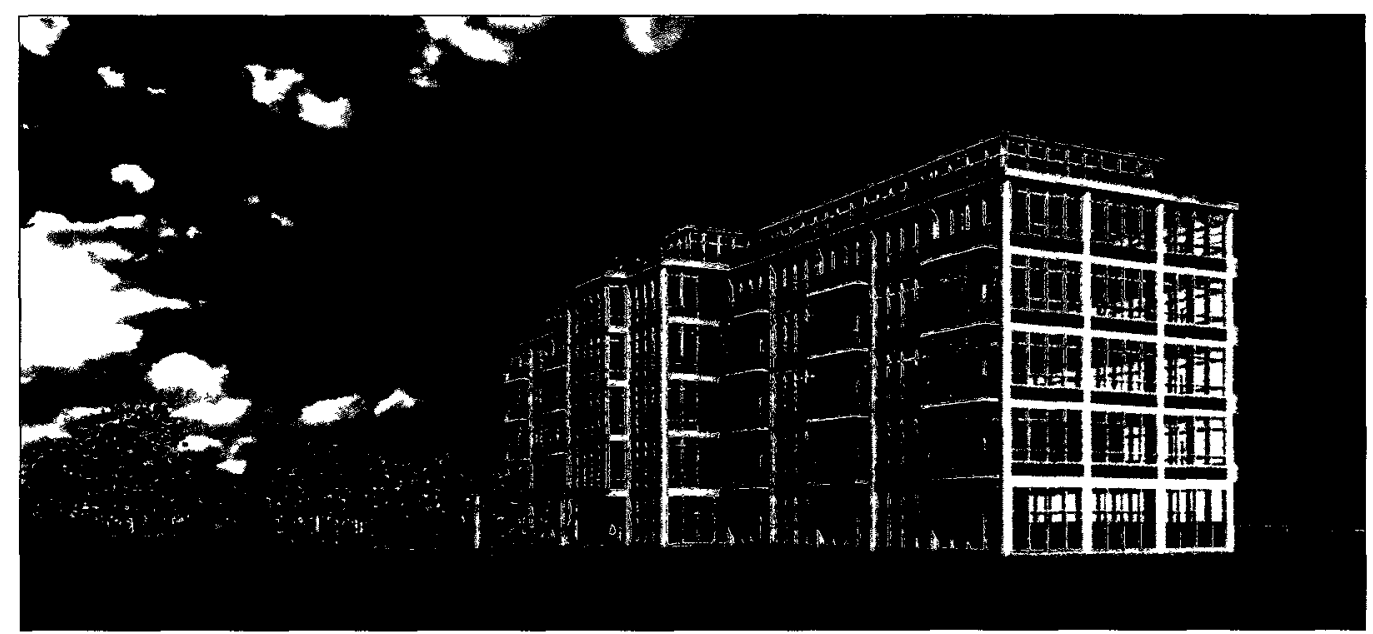

Figure 24: Proposed Condominium Project for the Bata Shoe Factory, by Zeidler Partnership Architects.

The current proposal is, in many respects, a new Utopian Project in the making. It is based on the pertinent moral imperative of environmentalism and sustainability, with an ideal target population, and a nostalgic bias for a mind's eye picture of the factory in its original form, before it had become adapted to its context. While there is nothing inherently wrong with any of these elements, to reestablish Batawa as a "model" utopian community would simply reset an inevitable life-cycle in the town which only recently culminated in its premature obsolescence.

${ }^{7}$ http://batawa.ca/index.php 
The Factory's history demonstrates an alternate, heterotopian approach. Through its many alterations over time the Factory has become the product of an ongoing dialogue between an architectural idea and a distinct geographic, cultural and temporal context. Yet despite its many adaptations, its primary function remained constant-confined by its utopian program-to the point of its obsolescence. In the future, if the Factory can be made adaptable programmatically, through dialogue, as it has already proven adaptable tectonically, than it will become resilient amid the "forces of change" that will cause future Utopian Projects to be swept away.

This thesis proposes, therefore, a heterotopian architectural intervention in the factory through which its timeline will continue on a trajectory of adaptation through dialogue. In this proposal, the factory will regain its identity as an economic generator in the community by hosting two contrasting programs. The first program is a community garden. By removing the factory's floor and ceiling surfaces, the space between the exposed beams will function as alternating planting troughs and light wells. This program will once again make the factory a place of communal gathering. Garden plots can be used either leisurely by the town's residents or for commercial enterprises such as local restaurants or markets.

The second program is a data centre. This program will bring a significant source of economy to Batawa by attracting technology companies to the area, either physically or remotely. One of the main concerns with operating a data center is controlling the heat generated by the computer stacks. This byproduct creates a unique opportunity for the garden, since the excess heat could be harnessed to help to sustain growth year-round. Since the Factory is positioned in a north/south orientation onsite, the area along the central spine of the building receives the least amount of natural light. The data center will therefore occupy this darkest area of the structure, while the garden will be located at the edges. Another consideration for data center design is that they be scalableable to grow or shrink as demand and technology change over time. The Batawa Data Center will be built in a modular system which will fit within the existing modular frame of the Factory. On each floor, the data center will sit on the Factory's exposed beams and be subdivided by its grid of columns. Within each of the Factory's bays, a data center 
"pod" will be composed of standard lateral segments which can be easily added or subtracted to increase or decrease the size of the pod as needed.

If this architectural dialogue is successful, it is foreseeable that supplemental programs could also be accommodated over time. Some pods could be converted from server rooms to offices, restaurants, community facilities or even residential units. The Factory would be spatially and functionally distributed according to an ongoing negotiation between interdependent programs; the outcome would be an architectural ecology that is never entirely static. 

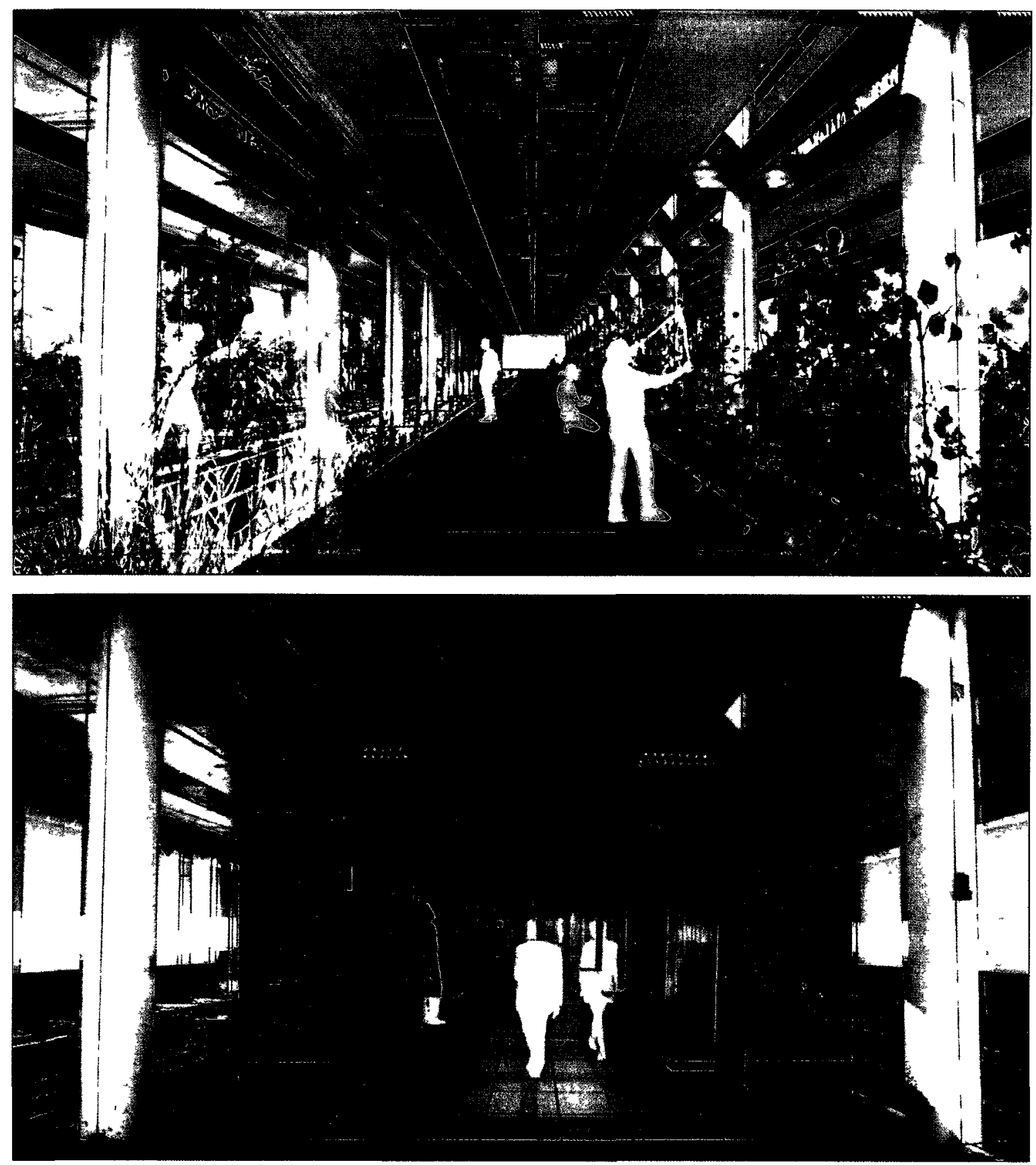

Figure 25: Two Proposed Programs, a communty garden and a data center 

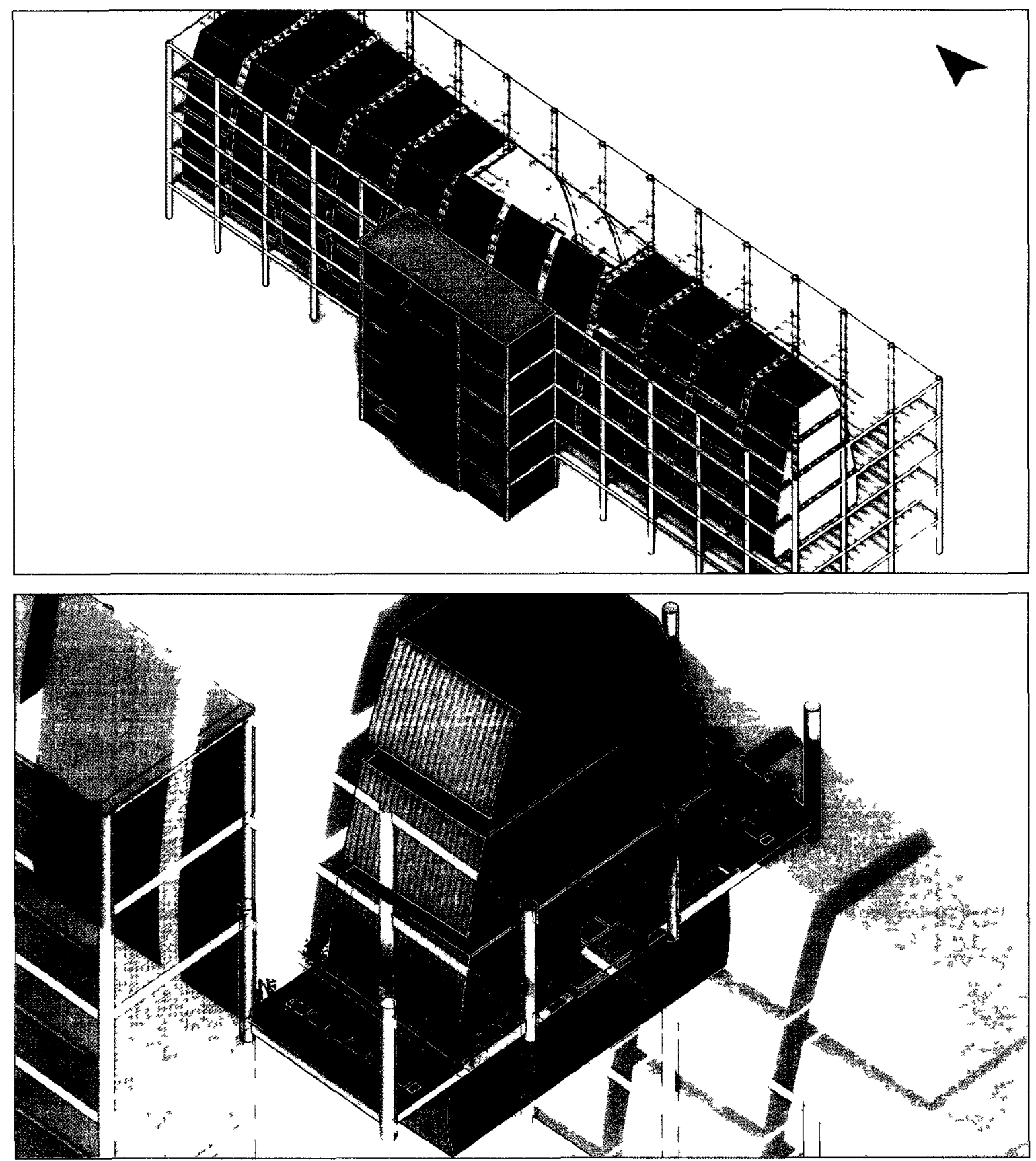

Figure 26 Proposed intervention 

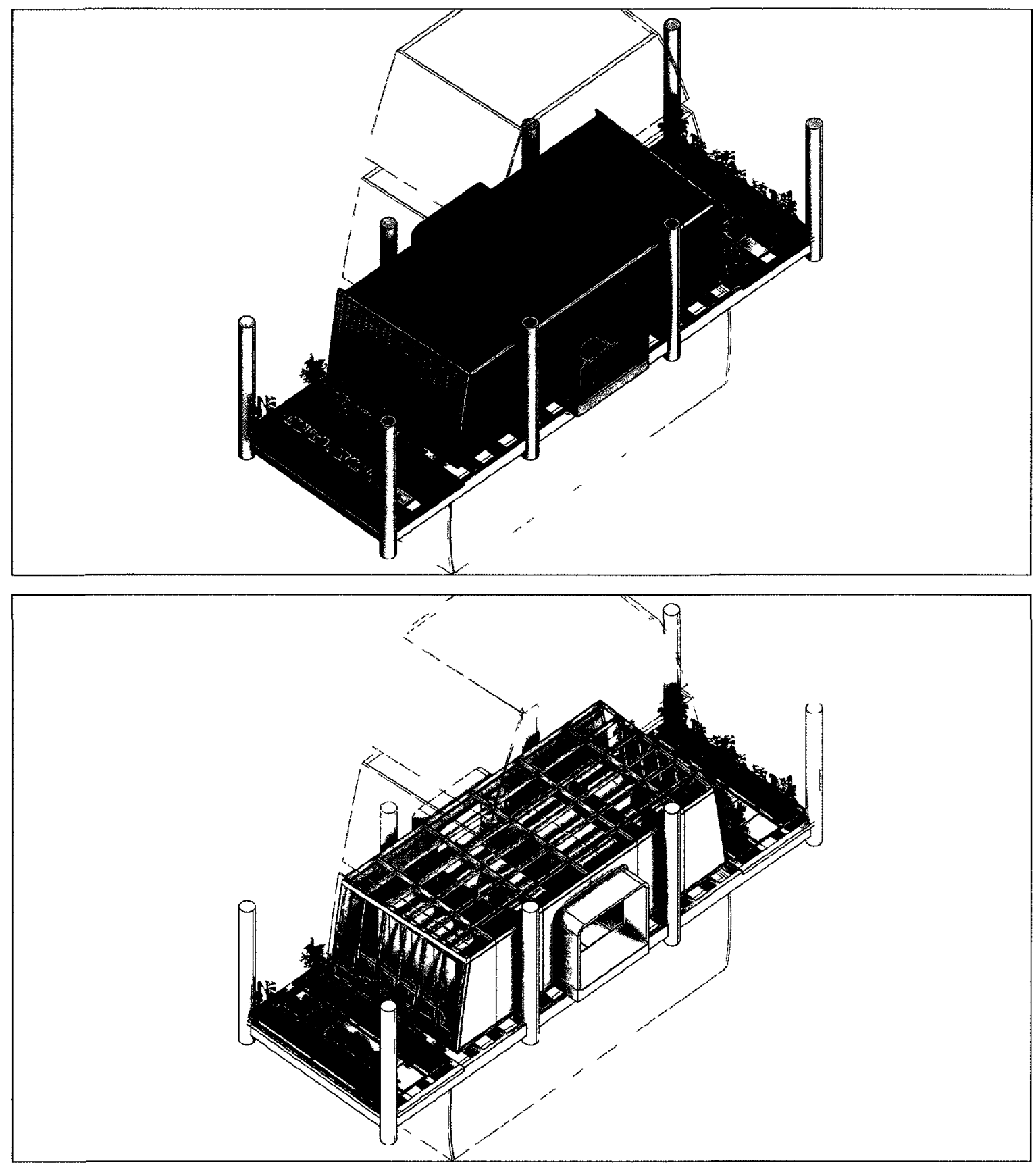

Figure 27 Detall of a typical modular "pod" 

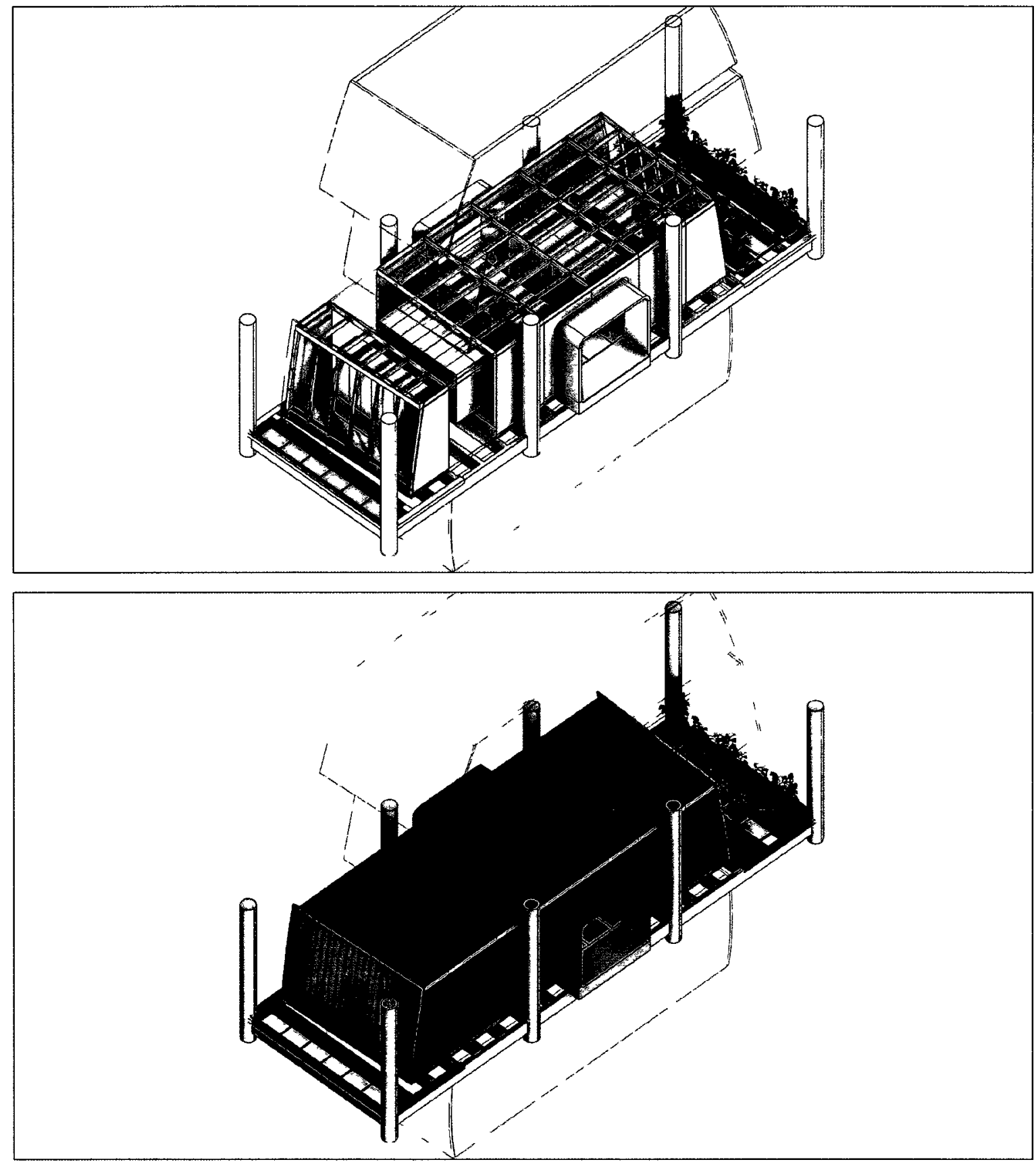

Figure 28 Demonstration of a modular "pod" alteration 



\section{Conclusion}

The brief history of Batawa, Ontario has spanned the gap between a utopian and a postutopian paradigm - from Plato to Foucault in less than seventy years. Like all Utopian Projects, the realization of an ideal in Batawa was partial and it was momentary. With the closure of the factory, the utopian syntax of the town has gradually disassembled and dispersed. In this sense, both the story of Batawa and the broader discourse on spatial theory in the twentieth century can be characterized as the victory of one polemic over another. Now, current plans for development in Batawa indicate another possible pendulum swing - the resurgence of a utopian paradigm as a proposed future.

I have argued that the 'either or,' polemic of spatial theory, descending from a literal interpretation of Plato's and More's programs, stifles the vitality of real places by resisting context and discourse in favour of static solutions.

Foucault advocates an alternate interpretation of the utopia/heterotopia opposition. By identifying heterotopias as practical realizations of utopias, he is extending the discourse begun by Plato, not discrediting it. What I have called a post-polemic view of heterotopia presents a context in which perceived opposites no longer preclude one another but rather exist in continued dialogue. This alternate way of reading Batawa's history correspondingly points to an alternate approach for considering the future that, I theorize, would bypass the rapid cycle of renewal to obsolescence. The project I have proposed, therefore, resists the inclination towards the image of a new static ideal-the reestablishment of a Utopian Project. Instead, I have reconstructed a heterotopian dialogue between idea and context along a timeline of Batawa's past, and I have proposed an architectural intervention that will extend this dialogue into Batawa's future. 
Bata, Tomas. Knowledge in Action: The Bata System of Management. Amsterdam: IOS Press, 1992.

Castells, Manuel. The Rise of the Network Society. Cambridge: Blackwell Publishers Inc., 1996.

Cekota, Anthony. The Stormy Years of an Extraordinary Enterprise. New Jersey: Universum Sokol Publications, 1985.

Dehaene, Michiel \& De Cauter, Lieven. Heterotopia and the City. New York: Routledge, 2008.

Eco, Umberto. Interpretation and Overinterpretation. Cambridge: Cambridge University Press, 1992.

Fishman, Robert. Urban Utopias in the Twentieth Century. New York: Basic Books, Inc., 1977.

Foucault, Michel. "Of Other Spaces, (1967) Heterotopias." Architecture/Mouvement/ Continuité. Translated by Jay Miskowiec. 1984.

Forty, Adrian. "Language and Drawing." Words and Buildings. A Vocabulary of Modern Architecture. New York: Thames and Hudson, 2000: 29-41

Foucault, Michel. This is Not a Pipe. Los Angeles, University of California Press, 1983.

Frampton, Kenneth. Modern Architecture. A Critical History. London: Thames \& Hudson, 2007.

Grandin, Greg. Fordlandia. The Rise and Fall of Henry Ford's Forgotten Jungle City. New York. Metropolitan Books, 2009.

Harbison, Robert. The Built, the Unbuilt and the Unbuildable: In pursuit of Architectural Meaning. Cambridge, Massachusetts, The MIT Press, 1991

Hetherington, Kevin. The Badlands of Modernity. Heterotopia and Social Ordering. London: Routledge, 1997.

Heynen, Hilde \& Jan Henket, Hubert. Back from Utopia: The Challenge of the Modern Movement. Rotterdam: 010 Publishers, 2002.

Hornakova, Ladislava. The Bata Phenomenon. Zlin Architecture, 1910-1960. Zlin: Regional Galerie of Fine Arts, 2009.

Jameson, Frederic. Archaeologies of the Future. The Desire Called Utopia and Other Science Fictions. London: Verso, 2005. 
More, Thomas. Utopia. With introduction by Clarence H. Miller. New Haven CT: Yale University Press, 2001.

Mumford, Lewis. The City in History: its origins, its transformations and its prospects. New York: Harcourt, Brace \& World, 1961.

Pevsner, Nikolaus. The Sources of Modern Architecture and Design. Toronto: Oxford University Press, 1968.

Plato. The Republic. Translated by Richard W. Sterling and William C. Scott. New York: Norton, c1985, 1996.

Ricketts, Shannon. "Batawa. An Experiment in International Standardization." SSAC Bulletin SEAC 18:3/4, 1992

Sorkin, Michael. "Eutopia Now!" Harvard Design Magazine 31. Fall/Winter 2009/10.

Wiebenson, Dora. Tony Garnier: The Cite Industrielle. New York: Geroge Braziller, 1969. 